Report No. BMI-1165

Metallurgy and Ceramics (TID-4500, 12th Ed.)

\title{
I
}

Contract No. W -7405-eng -92

\section{PROPERTIES OF BERYLLIUM OXIDE AND CARBIDES OF BERYLLIUM, MOLYBDENUM, NIOBIUM, TANTALUM, AND TITANIUM}

by

William P. Weber

John F. Quirk

Alexis W. Lemmon, Jr.

Robert B. Filbert, Jr.

February 11, 1957

BATTELLE MEMORIAL INSTITUTE

$505 \mathrm{King}$ Avenue

Columbus 1, Ohio 


\section{DISCLAIMER}

This report was prepared as an account of work sponsored by an agency of the United States Government. Neither the United States Government nor any agency Thereof, nor any of their employees, makes any warranty, express or implied, or assumes any legal liability or responsibility for the accuracy, completeness, or usefulness of any information, apparatus, product, or process disclosed, or represents that its use would not infringe privately owned rights. Reference herein to any specific commercial product, process, or service by trade name, trademark, manufacturer, or otherwise does not necessarily constitute or imply its endorsement, recommendation, or favoring by the United States Government or any agency thereof. The views and opinions of authors expressed herein do not necessarily state or reflect those of the United States Government or any agency thereof. 


\section{DISCLAIMER}

Portions of this document may be illegible in electronic image products. Images are produced from the best available original document. 


\section{TABLE OF CONTENTS}

ABSTRACT . . . . . . . . . . . . . . . . . . . . . . . . . . . 1

INTRODUCTION . . . . . . . . . . . . . . . . . . . . . . . . . . . . . . . .

PROPERTIES OF NIOBIUM CARBIDE . . . . . . . . . . . . . . . . . . . . . . . . . . . 2

Chemical Properties . . . . . . . . . . . . . . . . . . . . . . . . . 2

Composition; Corrosion; Resistance to Oxidizing and/or Reducing Atmospheres.

Physical-Chemical Properties . . . . . . . . . . . . . . . . . . . . . . . . . 3

Heat, Entropy, and Free Energy of Formation; Absolute Entropy; Thermal Stability .

Physical Properties . . . . . . . . . . . . . . . . . . . . . . . . . . 4

Density; Electrical and Magnetic Properties; Melting Point; Boiling Point; Molecular Structure;

Lattice Constant; Thermal Conductivity; Vapor Pressure.

Mechanical Properties . . . . . . . . . . . . . . . . . . . . . . . . . 5

Hardness; Modulus of Elasticity.

General Properties . . . . . . . . . . . . . . . . . . . . . . . . . 6

Preparation, Fabrication, and Production Methods; Availability.

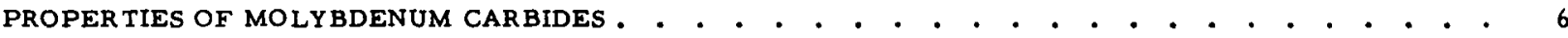

Chemical Properties. . . . . . . . . . . . . . . . . . . . . . . . . . . 7

Composition: Corrosion and Compatibility; Resistance to Oxidizing and/or Reducing Atmospheres.

Physical-Chemical Properties . . . . . . . . . . . . . . . . . . . . . . . . . 8

Heat, Entropy, and Free Energy of Formation; Absolute Entropy; Thermal Stability.

Physical Properties . . . . . . . . . . . . . . . . . . . . . . . . . . . . .

Density; Electrical and Magnetic Properties; Melting Point; Molecular Structure; Lattice

Constants; Phase Changes.

Mechanical Properties . . . . . . . . . . . . . . . . . . . . . . . . 10

Hardness; Modulus of Elasticity.

General Properties . . . . . . . . . . . . . . . . . . . . . . . . . . . 10

Preparation, Fabrication and Production Methods.

PROPERTIES OF TANTALUM CARBIDES . . . . . . . . . . . . . . . . . . . . . . . . 11

Chemical Properties . . . . . . . . . . . . . . . . . . . . . . . . . . 11

Composition; Corrosion; Resistance to Oxidizing and/or Reducing Atmospheres.

Physical-Chemical Properties . . . . . . . . . . . . . . . . . . . . . . . . . 12

Heat, Entropy, and Free Energy of Formation; Absolute Entropy; Heat Capacity, Thermal Stability. 


\section{III}

\section{TABLE OF CONTENTS}

(Continued)

Physical Properties . . . . . . . . . . . . . . . . . . . . . . . . . . . .

Density; Electrical and Magnetic Properties; Melting Point; Boiling Point; Structure; Lattice Constants; Phase Properties; Thermal Conductivity; Coefficient of Thermal Expansion; Emissivity.

Mechanical Properties . . . . . . . . . . . . . . . . . . . . . . . . . . .

Tensile Strength; Hardness; Modulus of Elasticity.

General Properties . . . . . . . . . . . • . . . . . . . . . . . . . . . .

Preparation, Fabrication, and Production Methods; Availability.

PROPER TIES OF TITANIUM CARBIDE

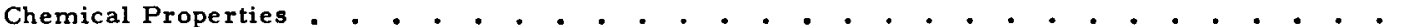

Composition; Corrosion and Compatibility; Resistance to Oxidizing and/or Reducing Atmospheres.

Physical-Chemical Properties . . . . . . . . . . . . . . . . . . . . . . . . .

Heat, Entropy, and Free Energy of Formation; Absolute Entropy; Entropy and Enthalpy;

Heat Capacity; Thermal Stability.

Physical Properties . . . . . . . . . . . . . . . . . . . . . . . . . . .

Density; Electrical and Magnetic Properties; Melting Point; Boiling Point; Molecular Structure; Lattice Constants; Phase Changes; Thermal Conductivity; Coefficient of Thermal Expansion;

Vapor Pressure; Emissivity.

Mechanical Properties . . . . . . . . . . . . . . . . . . . . . . . . . .

Compressive Strength; Tensile Properties; Rupture; Hardness; Modulus of Elasticity.

General Properties . . . . . . . . . . . . . . . . . . . . . . . . . . .

Preparation, Fabrication, and Production Methods.

PROPERTIES OF BERYLLIUM OXIDE . . . . . . . . . . . . . . . . . . . . . . . . . . . .

Chemical Properties . . . . . . . . . . . . . . . . . . . . . . . . . . .

Composition; Corrosion; Resistance to Oxidizing and/or Reducing Atmospheres.

Physical-Chemical Properties. . . . . . . . . . . . . . . . . . . . . . . . .

Heat, Entropy, and Free Energy of Formation; Heat and Entropy of Fusion; Heat and Entropy of Vaporization; Heat of Sublimation; Entropy, Enthalpy, and Free Energy; Heat Capacity.

Physical Properties . . . . . . . . . . . . . . . . . . . . . . . . . . .

Density; Electrical and Magnetic Properties; Melting Point; Boiling Point; Structure; Lattice Constants; Phase Properties; Thermal Conductivity; Coefficient of Thermal

Expansion; Vapor Pressure; Emissivity.

Mechanical Properties . . . . . . . . . . . . . . . . . . . . . . . . . .

Tensile Strength; Compressive Strength; Hardness; Modulus of Elasticity. 


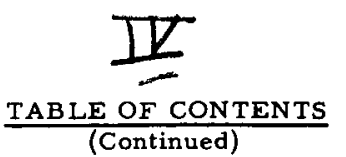

Page

General Properties . . . . . . . . . . . . . . . . . . . . . . . . . . . 29

Preparation, Fabrication, and Production Methods; Toxicity.

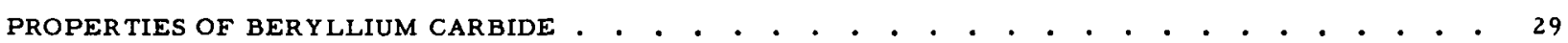

Chemical Properties. . . . . . . . . . . . . . . . . . . . . . . . . . . . . 29

Corrosion; Erosion; Resistance to Oxidizing and/or Reducing Atmospheres.

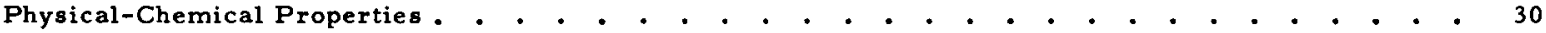

Free Energy of Formation; Heat Capacity.

Physical Properties . . . . . . . . . . . . . . . . . . . . . . . . . . . . . 30

Density; Electrical and Magnetic Properties; Melting Point; Structure; Lattice Constants;

Thermal Conductivity; Coefficient of Thermal Expansion; Vapor Pressure.

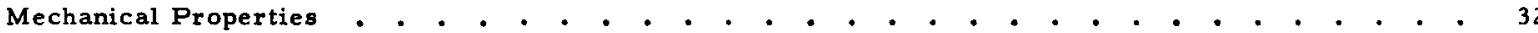

Compressive Strength; Modulus of Elasticity; Poisson's Ratio; Hardness.

General Properties . . . . . . . . . . . . . . . . . . . . . . . . . . . . . 32

Preparation, Fabrication, and Production Methods; Toxicity.

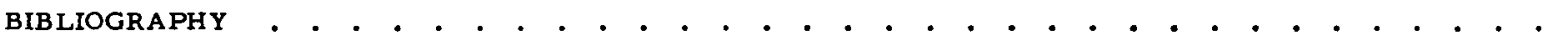

APPENDIX

SUMMARY OF PROPERTIES OF HIGH-TEMPERATURE MATERIALS . . . . . . . . . . . . . A- 


\title{
1 \\ PROPER TIES OF BERYLLIUM OXIDE AND CARBIDES OF BERYLLIUM, MOLYBDENUM, NIOBIUM, TANTALUM, AND TITANIUM
}

\author{
William P. Weber, John F. Quirk, Alexis W. Lemmon, Jr., \\ and Robert B. Filbert, Jr.
}

\begin{abstract}
The available data on the chemical, physical-chemical, and physical properties of several refractory materials are summarized and evaluated. The compilation covers beryllium oxide and the carbides of beryllium, niobium, molybdenum, tantalum, and titanium. A summary table of properties and a complete reference bibliography are included.
\end{abstract}

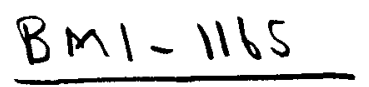

INTRODUCTION

A major problem in many of today's more advanced technologies is the lack of pertinent data on the properties of materials useful at high temperatures. Much of the available data have been brought together in two recent books, Refractory Hard Metals by Schwarzkopf and Kieffer $(43) *$, and High-Temperature Technology, edited by I. E. Campbell(11). However, in certain instances, these and other reviews are less complete than would be desired. Moreover, because of the great activity in this field, new data are being published with increasing frequency.

The present report is based on a literature survey designed to gather the most reliable, recent, and complete data available on the properties of beryllium oxide, and the carbides of beryllium, molybdenum, niobium, tantalum, and titanium. There is, of course, a practical limit in the degree of approach to this goal of completeness and reliability, since it has not been possible to consult all of the original references encountered in the literature search. However, the available library is large, and it can be hoped that the deficiency in that regard is limited.

The starting point for the literature survey has been a review of the standard works on high-temperature materials and of Chemical Abstracts from 1930 to mid1955. In that way, a reasonable degree of completeness should have been achieved.

It is unfortunate that property values and other information reported in the literature gain credence almost as much in repetition as in confirmation. Thus, one must be alert for inconsistencies and poorly determined values. To track down and evaluate the data in every instance would be an insurmountable task. However, in the course of preparing this report, many inconsistencies have been resolved and it is hoped that no gross errors have been perpetuated.

It will readily become apparent to the reader that the major gaps in our knowledge of the materials covered here lie in the areas of high-temperature mechanical properties, volatility, and resistance to corrosion in various atmospheres.

References are listed in the Bibliography at the end of the report. 
Information on $\mathrm{NbC}$ is not extensive in the literature. Reliable values for some of the more readily measurable properties such as the melting point, density, resistivity, thermal conductivity, and hardness are available.

A good experimentally determined value for the heat of formation has been reported. This, coupled with an entropy value estimated by the method of Latimer, yields a value for the free energy of formation which is believed reliable. No other experimental thermodynamic values have been reported.

No quantitative values are available for the vapor pressure, dissociation constant, or mechanical properties.

\section{Chemical Properties}

\section{Composition}

The composition of two forms of NbC commercially available from the $\mathrm{F}$ ansteel Metallurgical Corporation are reported by Schwartz(42).

\begin{tabular}{lcc} 
& \multicolumn{2}{c}{ Analysis, w/o } \\
\cline { 2 - 3 } Commercial & $\begin{array}{c}\text { Commercial } \\
\text { High Purity }\end{array}$ & $\frac{11.0-11.5}{11.0-11.5}$ \\
Tantalum & 0.25 & 2.5 \\
Titanium & 0.002 & 1.2 \\
Iron & 0.002 & 0.3 \\
Silicon & 0.003 & -- \\
Tin & -- & Trace
\end{tabular}

Niobium Remainder Remainder

\section{Corrosion}

The best available information, which is reported by Campbell (11), indicates that $\mathrm{NbC}$ is soluble only in $\mathrm{HF}$ plus $\mathrm{HNO}_{3}$.

\section{$\underline{\text { Erosion }}$}

No information is available in the literature. 
Resistance to Oxidizing and/or Reducing

Atmospheres

No quantitative data are available. However, the following reliable qualitative information has been reported:

$\mathrm{NbC}$ is stable to $2500 \mathrm{C}$ in a nitrogen atmosphere. It decarburizes slightly when heated in air (11).

In the presence of nitrogen, it is attacked only near its melting point (42).

On heating NbC powder in air, it burns with a bright flash(43).

This is one area where quantitative data are badly needed. Work should be done on the effect of various atmospheres on $\mathrm{NbC}$ at high temperatures.

\section{Physical-Chemical Properties}

\section{Heat, Entropy, and Free Energy} of Formation

A value for the heat of formation, $\Delta \mathrm{H}_{\mathrm{f} 298.16}^{\circ}=-33.6+0.8 \mathrm{kcal}$ per $\mathrm{g}$ mole, determined by combustion calorimetry, has been reported by Mah and Boule(34). Since careful experimental techniques were used, this figure is believed to be the most accurate available.

Latimer's method was used by Brewer and Krikorian(7) to estimate the entropy of formation, $\Delta \mathrm{S}_{\mathrm{f} 298}^{\circ}=-1.4 \pm 1 \mathrm{cal} / \mathrm{g}(\mathrm{mole})(\mathrm{K})$. This value is sufficiently accurate to permit its use in calculation of the free energy of formation $\left(\Delta F_{f}\right)$.

From the above, the free energy of formation, $\Delta F_{\text {f } 298.16}$, is calculated from the expression $\Delta F=\Delta H-T \Delta S$ to be $-33.2 \mathrm{kcal}$ per $\mathrm{g}$ mole. This supersedes the value reported by Campbell(11) which was based on a heat of formation, $\Delta \mathrm{H}_{\mathrm{f}}^{\circ} 298$, of $-30.0 \mathrm{kcal}$ per $g$ mole.

Absolute Entropy, Heat Capacity, Enthalpy, and Free Energy

No experimental data have been obtained. An estimated value of the entropy, $\mathrm{S}_{298}=9.0 \pm 1.5 \mathrm{cal} /(\mathrm{g}$ mole $)(\mathrm{K})$, is reported by Kubachewski and Evans $(28)$. Heatcapacity determinations should be carried out.

Heat of Dissociation, Dissociation Constant

No information is available in the literature. 


\section{Thermal Stability}

Schwartz(42) reports that $\mathrm{NbC}$ will melt without decomposing when heated in a vacuum or an inert atmosphere.

Heat of Fusion, Heat of Transition

No information is available in the literature.

\section{Physical Properties}

Density

A density for $\mathrm{NbC}$ of $7.82 \mathrm{~g}$ per $\mathrm{cm}^{3}$ was measured by McKenna(36) and has been recommended by several authors $(11,42,44)$.

\section{Electrical and Magnetic Properties}

The electrical resistivity has been reported by Schwarzkopf and Kieffer (43) to be $7.4 \times 10^{-5} \mathrm{ohm}-\mathrm{cm}$ at room temperature. This value has been recommended by Campbell(11). Schwartz(42) gives $3 \times 10^{-4}$ to $4 \times 10^{-4} \mathrm{ohm}-\mathrm{cm}$ at the melting point and indicates that $\mathrm{NbC}$ is superconducting at $10.1 \mathrm{~K}$.

\section{Melting Point}

Several authors $(6,11,42,43)$ report the melting point of $\mathrm{NbC}$ as $3500 \mathrm{C}$.

\section{Boiling Point}

Schwartz(42) and Campbell(11) recommend a value of $4300 \mathrm{C}$ for the boiling point as obtained by Mott (1918).

\section{Molecular Structure}

The structure of $\mathrm{NbC}$ is face-centered-cubic ( $\mathrm{NaCl}$ type) according to Schwartz(42).

\section{Lattice Constant}

Values for the lattice constant have been reported as:

A Units
$\begin{gathered}4.458 \\ 4.4584 \text { to } 4.462 \\ 4.461\end{gathered}$

4.461
Campbell(11)

Mallet and Sheipline(35)

Schwarzkopf and Kieffer (43) 
The calculated interplanar spacings (a) and intensities $\left(\mathrm{I} / \mathrm{I}_{\mathrm{O}}\right)$ of $\mathrm{NbC}$ are given by Schwartz(42) as follows:

$\begin{array}{lll}\frac{a, A}{2.54} & & \frac{I / I_{o}}{1.00} \\ 2.20 & & 0.70 \\ 1.56 & & 0.43 \\ 1.33 & & 0.38 \\ 1.27 & & 0.16 \\ 1.10 & & 0.10 \\ 1.01 & & 0.34 \\ 0.984 & & 0.52\end{array}$

\section{Phase Changes}

No information is available in the literature.

\section{Thermal Conductivity}

Schwarzkopf and Kieffer (43) report the thermal conductivity at $20 \mathrm{C}$ to be $0.034 \mathrm{cal} /(\mathrm{sec})\left(\mathrm{cm}^{2}\right)(\mathrm{C} / \mathrm{cm})$.

\section{Coefficient of Thermal Expansion}

No information is available in the literature.

\section{Vapor Pressure}

No quantitative information is available in the literature. However, Schwarzkopf and Kieffer ${ }^{(43)}$ report that $\mathrm{NbC}$ is slowly volatile at $2500 \mathrm{~K}$ in a vacuum $\left(10^{-3}\right.$ to $10^{-5} \mathrm{~mm}$ of mercury).

\section{Mechanical Properties}

No information on the coefficient of compressibility, compressive strength, tensile properties, creep or rupture is available in the literature.

\section{Hardness}

Schwartz(42) and Campbell(11) give a Mohs hardness number of 9 to 10 , while Smithells (44) and Schwarzkopf and Kieffer ${ }^{(43)}$ list the microhardness as $2400 \mathrm{~kg}$ per $\mathrm{mm}^{2}$ with a $100-\mathrm{g}$ load. 


\section{Modulus of Elasticity}

A value of $49.4 \times 10^{6} \mathrm{psi}$ for $\mathrm{NbC}$ is reported by Schwarzkopf and Kieffer (43).

\section{General Properties}

Preparation, Fabrication, and Production Methods

According to Campbell(11), the carbides $\mathrm{NbC}, \mathrm{HfC}, \mathrm{TaC}, \mathrm{TiC}, \mathrm{UC}$, and $\mathrm{ZrC}$ can be made in the laboratory by heating the respective metal hydrides to about $2100 \mathrm{C}$ in a graphite crucible.

Stoichiometric monocarbides of niobium, tantalum, and titanium can be produced by reacting the metal or metal oxide with carbon in a molten metallic menstruum at 1800-2000 C. The pure microcrystals remain after impurities are removed by acid leaching and gravity separation.

Brewer and Krikorian( 7 have produced a carbide mix containing mainly $\mathrm{Nb}_{2} \mathrm{C}$ by reacting a mixture containing $75 \mathrm{w} / 0$ of niobium and $25 \mathrm{w} / 0$ of carbon at $1920 \mathrm{~K}$ in a molybdenum crucible.

Campbell(11) reports that satisfactory methods for fabricating NbC are hot pressing, steel-die pressing, and sintering.

\section{$\underline{\text { Toxicity }}$}

No information is available in the literature.

\section{Availability}

Schwartz(42) indicates that $\mathrm{NbC}$ may be purchased in the form of powder having a particle size of 30 mesh or finer from the Fansteel Metallurgical Corporation, North Chicago, Illinois.

\section{PROPERTIES OF MOLYBDENUM CARBIDES}

Various investigators have disagreed as to the existing stable phases of the molybdenum-carbon system. It has recently been established that there are two stable carbides of molybdenum, $\mathrm{Mo}_{2} \mathrm{C}(\beta$-phase) and $\mathrm{MoC}(\gamma$-phase), and Kuo and Hägg (29) have presented evidence of a third phase ( $\gamma^{\prime}$-phase) which is probably also of the composition MoC. The $\gamma$-phase and $\gamma^{\prime}$-phase are not of primary importance in this investigation since the $\gamma^{\circ}$-phase is rapidly transformed to the $\gamma$-phase above $800 \mathrm{C}$, and the freeenergy values indicate that at high temperatures the $\gamma$-phase $M \circ C$ is decomposed to $\beta$-phase $\mathrm{Mo}_{2} \mathrm{C}$. 
The data presented in the literature on the properties of the molybdenum carbides are not extensive. Reliable values are given for the melting point, density, electrical resistivity, and hardness. The values given for the heat of formation, entropy of formation, and free energy of formation are also believed to be reliable.

No quantitative data are available for the vapor pressure, dissociation constant, thermal stability, resistance to reducing atmospheres, or mechanical properties.

\section{Chemical Properties}

\section{Composition}

The theoretical carbon content of $\mathrm{Mo}_{2} \mathrm{C}$ is $5.89 \mathrm{w} / \mathrm{o}$ and that of $\mathrm{MoC}$ is $11.13 \mathrm{w} / \mathrm{o}$.

\section{Corrosion and Compatibility}

According to Schwarzkopf and Kieffer (43), $\mathrm{Mo}_{2} \mathrm{C}$ powder is stable in nonoxidizing acids but is dissolved by nitric acid and aqua regia. $\mathrm{MO}_{2} \mathrm{C}$ powder reacts with chlorine at elevated temperatures and with fluorine at room temperature.

Schwarzkopf and Kieffer (43) state that MoC powder is not attacked by steam at $600 \mathrm{C}$. It completely dissolves in concentrated HF, is decomposed by cold nitric acid and boiling sulfuric acid, is barely attacked by concentrated $\mathrm{HCl}$, and resists cold $\mathrm{KOH}$ and $\mathrm{NaOH}$ solutions. The $\mathrm{MoC}$ powder reacts with chlorine and bromine at elevated temperatures but is only superficially attacked by iodine.

\section{$\underline{\text { Erosion }}$}

No information is available in the literature on erosion of molybdenum carbides.

Resistance to Oxidizing and/or Reducing Atmospheres

The molybdenum carbides have poor stability in oxidizing atmospheres. According to Schwarzkopf and Kieffer $(43)$, both $\mathrm{MO}_{2} \mathrm{C}$ and $\mathrm{MoC}$ powders oxidize when heated in air, and Powell, et al. (39), state that coatings of $\mathrm{MoC}$ and $\mathrm{Mo}_{2} \mathrm{C}$ are rapidly attacked by air at 700-800 C. The molybdenum carbides are less stable than the other hardmetal carbides $(11)$.

There is a definite need for quantitative data in this area. The data on the resistance of the molybdenum carbides to oxidizing atmospheres are very general, and the only information on resistance to reducing atmospheres is given by Campbell(11), who states that the "hard-metal" carbides resist reducing atmospheres. 
Physical-Chemical Properties

Heat, Entropy, and Free Energy of

Formation

Browning and Emmett(9) give values for the free energy of formation at $950 \mathrm{~K}$ of $\Delta F_{\text {f } 950}^{\circ}=-8.862 \mathrm{kcal}$ per $\mathrm{g}$ mole for $\mathrm{Mo}_{2} \mathrm{C}$ and $\Delta \mathrm{F}_{\mathrm{f} 950}^{\circ}=-3.211 \mathrm{kcal}$ per $\mathrm{g}$ mole for MoC. Brewer and Krikorian (7) calculated the heat of formation from these data as $\Delta \mathrm{H}_{\mathrm{f} 298}^{\circ}=-4.22 \pm 1.09 \mathrm{kcal}$ per $\mathrm{g}$ mole for $\mathrm{Mo}_{2} \mathrm{C}$ and as $\Delta \mathrm{H}_{\mathrm{f} 2}^{\circ} 98=-2.00 \pm 0.65 \mathrm{kcal}$ per $\mathrm{g}$ mole for $\mathrm{MoC}$.

Brewer and Krikorian(7) give values for the entropy of formation of $\mathrm{Mo}_{2} \mathrm{C}$ as $\Delta \mathrm{S}_{\mathrm{f} 298}^{\circ}=2.4 \pm 1 \mathrm{cal} /(\mathrm{g}$ mole $)(\mathrm{K})$ and that of $\mathrm{MoC}$ as $\Delta \mathrm{S}_{\mathrm{f} 298}^{\circ}=0.0 \pm 1 \mathrm{cal} /(\mathrm{g} \mathrm{mole})(\mathrm{K})$.

The free energy of formation can be calculated from the data on heat of formation and entropy of formation given above. These values are $\Delta F_{\mathrm{f} 298}^{\circ}=-4.93 \mathrm{kcal}$ per $\mathrm{g}$ mole for $\mathrm{Mo}_{2} \mathrm{C}$ and $\Delta \mathrm{F}_{\mathrm{f} 298}=-2.0 \mathrm{kcal}$ per $\mathrm{g}$ mole for $\mathrm{MoC}$.

\section{Absolute Entropy}

The entropy of $\mathrm{Mo}_{2} \mathrm{C}$ was calculated from the entropy of formation value of Brewer and Krikorian $(7)$ as $S_{\mathrm{f} 298}^{\circ}=17.42 \mathrm{cal} /(\mathrm{g} \mathrm{mole})(\mathrm{K})$.

Heat Capacity, Enthalpy, and

Free Energy

No experimental work has been done on these properties. Heat-capacity determinations should be carried out.

Thermal Stability

No experimental data are given in the literature. However, Brewer, et al. (6), indicate that $\mathrm{MOC}$ is slowly volatile at $2500 \mathrm{~K}$ in a high vacuum. There is a definite need for information on the thermal stability, and especially on the thermal-shock resistance, of the molybdenum carbides.

Heat of Fusion and Heat of Transition

No information is available in the literature.

\section{Physical Properties}

\section{Density}

The density of $\mathrm{Mo}_{2} \mathrm{C}$ is $8.9 \mathrm{~g}$ per $\mathrm{cm}^{3}$ and that of $\mathrm{MoC}$ is $8.5 \mathrm{~g}$ per $\mathrm{cm}^{3}(11)$.

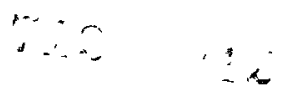


Electrical and Magnetic Properties

Schwarzkopf and Kieffer (43) give the specific electrical resistivity of $\mathrm{Mo}_{2} \mathrm{C}$ as $97.5 \mathrm{microhm}-\mathrm{cm}$ at $20 \mathrm{C}$ and $181 \mathrm{microhm}-\mathrm{cm}$ at the melting point, and of MoC as $49 \mathrm{microhm}-\mathrm{cm}$ at $20 \mathrm{C}$ and $70 \mathrm{microhm}-\mathrm{cm}$ at the melting point.

Schwarzkopf and Kieffer(43) also state that $\mathrm{Mo}_{2} \mathrm{C}$ and $\mathrm{MoC}$ become superconductive at 2.9 and $7.9 \mathrm{~K}$, respectively.

\section{Melting Point}

Not all of the literature sources agree on the melting point of the molybdenum carbides. Agte and Alterthum(1) give the melting point of $\mathrm{Mo}_{2} \mathrm{C}$ in the range 2685$2690 \mathrm{C}$, with MoC melting about $5 \mathrm{C}$ higher. These values are recommended by other authors $(6,11,35)$.

\section{Boiling Point}

No information is available in the literature on the boiling points of the molybdenum carbides.

\section{Molecular Structure}

According to Mallett and Sheipline(35), $\mathrm{Mo}_{2} \mathrm{C}$ has a hexagonal-close-packed structure and MoC has a simple hexagonal structure.

\section{$\underline{\text { Lattice Constants }}$}

Campbell(11) gives the lattice constants for $\mathrm{Mo}_{2} \mathrm{C}$ as $\mathrm{a}_{\mathrm{o}}=2.994 \mathrm{~A}$ and $\mathrm{c}_{\mathrm{o}}=4.722 \mathrm{~A}$. The lattice constants for $\mathrm{MoC}$ are given as $\mathrm{a}_{0}=2.901 \mathrm{~A}$ and $\mathrm{c}_{\mathrm{o}}=2.768 \mathrm{~A}$.

\section{Phase Changes}

A phase diagram of the molybdenum-carbon system is given by Sykes, et al. (45). $\mathrm{Mo}_{2} \mathrm{C}(\beta)$ and molybdenum form a eutectic at $1.8 \mathrm{w} / 0$ carbon and $2200 \mathrm{C}$.

Kuo and Hägg (29) have recently presented evidence indicating the existence of a third phase $\left(\gamma^{\prime}\right)$, in addition to the $\beta$-phase $\left(\mathrm{MO}_{2} \mathrm{C}\right)$ and $\gamma$-phase $(\mathrm{MOC})$, which probably also has the formula MoC. The $\gamma^{\prime}$-phase is formed following the carburization of molybdenum with $\mathrm{CO}$ at low temperatures and is rapidly converted to the $\gamma$-phase above $800 \mathrm{C}$.

Browning and Emmett(9) state that both $\mathrm{Mo}_{2} \mathrm{C}$ and $\mathrm{MoC}$ are stable with respect to their elements at $950 \mathrm{~K}$ but free-energy values are favorable for the reaction:

$$
2 \mathrm{MoC} \rightarrow \mathrm{Mo}_{2} \mathrm{C}+\mathrm{C} ; \Delta \mathrm{F}_{\mathrm{f} 950}=-2441 \mathrm{cal} \text { per } \mathrm{g} \text { mole. }
$$

This indicates that disproportionation is possible (thermodynamically) and that $\mathrm{Mo}_{2} \mathrm{C}$ is the more stable compound.

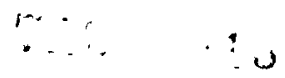




\section{Thermal Conductivity}

No information is available in the literature on the thermal conductivity of the carbides of molybdenum.

\section{Coefficient of Thermal Expansion}

No information is available in the literature on coefficients of expansion of the carbides.

\section{Vapor Pressure}

No experimental data on the vapor pressures of molybdenum carbides are available in the literature.

\section{Mechanical Properties}

No information is available in the literature on the coefficient of compressibility, compressive strength, tensile properties, creep, or rupture of the molybdenum carbides.

Hardness

The hardness of $\mathrm{MoC}$ and $\mathrm{Mo}_{2} \mathrm{C}$ is given by Mallett and Sheipline(35) as 7-8 Mohs and 7-9 Mohs, respectively.

The microhardness of $\mathrm{Mo}_{2} \mathrm{C}$ is given by Schwarzkopf and Kieffer(43) as $1800 \mathrm{~kg}$ per $\mathrm{mm}^{2}$.

Modulus of Elasticity

According to Schwarzkopf and Kieffer (43), the modulus of elasticity of $\mathrm{Mo}_{2} \mathrm{C}$ is $23,000 \mathrm{~kg}$ per $\mathrm{mm}^{2}\left(32.7 \times 10^{6} \mathrm{psi}\right)$.

\section{General Properties}

Preparation, Fabrication and Production Methods

Schwarzkopf and Kieffer $(43)$ describe the technical method of producing molybdenum carbide. Pure $\mathrm{MOO}_{3}$ is used as a starting material and is reduced under hydrogen at about $900 \mathrm{C}$ to metal powder. The metal powder is intimately mixed with sugar charcoal or carbon black (93.4 w/o molybdenum $-6.6 \mathrm{w} / \mathrm{o}$ carbon) and is carburized under hydrogen at 1400-1500 C. The carbide contains 6.05 to $6.10 \mathrm{w} / \mathrm{o}$ total carbon with only $0.15 \mathrm{w} / \mathrm{o}$ as free carbon. 
Satisfactory methods for fabricating the molybdenum carbides are sintering and hot pressing.

\section{PROPERTIES OF TANTALUM CARBIDES}

The thermodynamic properties of $\mathrm{TaC}$ are believed to be reliable. The heat of formation was calculated by Humphrey $(23)$ from his experimental data on heat of combustion. Humphrey then calculated the free energy of formation from his data on heat of formation and the entropy value of Kelley $(25)$.

The literature data on the physical and mechanical properties of tantalum carbide are fairly complete, and the reported values are believed to be reliable.

\section{Chemical Properties}

\section{Composition}

The theoretical carbon content of $\mathrm{TaC}$ is $6.23 \mathrm{w} / \mathrm{o}$ and of $\mathrm{Ta}_{2} \mathrm{C}$ is $3.2 \mathrm{w} / \mathrm{o}$. A typical analysis of $\mathrm{TaC}$ obtained from Fansteel Metallurgical Corporation is given by Fairchild writers $(4)$ :

$\begin{array}{lc}\text { Tantalum } & \text { Analysis, w/o } \\ \text { Carbon } & 93.06-93.16 \\ \text { Iron } & 6.12-6.22 \\ \text { Silicon } & 0.22\end{array}$

\section{Corrosion}

Schwarzkopf and Kieffer ${ }^{(43)}$ state that $\mathrm{TaC}$ is only slightly soluble in acids. According to Campbell(11), both $\mathrm{TaC}$ and $\mathrm{Ta} 2 \mathrm{C}$ are soluble in $\mathrm{HF}+\mathrm{HNO}_{3}$, and $\mathrm{TaC}$ is attacked by aqua regia and oxygen at high temperatures.

\section{Erosion}

No information is available in the literature on erosion of tantalum carbides.

\section{Resistance to Oxidizing and/or Reducing}

Atmospheres

Schwarzkopf and Kieffer(43) state that TaC powder, when ignited, burns in air with a bright flash. 
According to Fairchild authors (4):

(1) Hydrogen decarburizes TaC filaments.

(2) TaC is stable in pure nitrogen at $3600 \mathrm{~K}(3325 \mathrm{C})$, but $\mathrm{TaN}$ is formed if the nitrogen contains a trace of hydrogen.

(3) $\mathrm{TaC}$ is stable up to its melting point $(3875 \mathrm{C})$ in an atmosphere of 15 per cent nitrogen and 85 per cent argon.

(4) $\mathrm{TaC}$ is very sensitive to oxygen, burning at $800 \mathrm{C}$. Traces of oxygen (in a poor vacuum) cause decarburization and oxidation.

(5) The action of $\mathrm{H}_{2} \mathrm{O}$ vapor is similar to that of oxygen.

Brewer, et al. (6), state that $\mathrm{TaC}$ may be prepared at $1600-1700 \mathrm{C}$ in a hydrogen atmosphere. This may be reconciled with Item (1) above if it is considered that the temperature involved is not indicated. It is probable that $\mathrm{TaC}$ is stable in hydrogen to a fairly high temperature.

\section{Physical-Chemical Properties}

Heat, Entropy, and Free Energy of

\section{Formation}

The heat of formation of $\mathrm{Ta}_{2} \mathrm{C}$ is given by Brewer and Krikorian $(8)$ as $\Delta \mathrm{H}_{\mathrm{f} 2}^{\circ} 98=$ $-36 \pm 8 \mathrm{kcal}$ per $\mathrm{g}$ mole. Humphrey $(23)$ gives the heat of formation of $\mathrm{TaC}$ as $\Delta \mathrm{H}_{\mathrm{f} 298}^{\circ}=-38.5 \pm 0.6 \mathrm{kcal}$ per $\mathrm{g}$ mole. The value by Humphrey $(23)$ was calculated from his experimental data on heat of combustion.

The entropy of formation of $\mathrm{TaC}$ is given by Brewer and Krikorian(8) as $\Delta \mathrm{S}_{\mathrm{f} 298}=-1.19 \pm 0.1 \mathrm{cal} /(\mathrm{g} \mathrm{mole})(\mathrm{K})$. Brewer and Krikorian $(8)$ report the entropy of formation of $\mathrm{Ta}_{2} \mathrm{C}$ as $\Delta \mathrm{S}_{\mathrm{f} 298}^{\circ}=1.4 \pm 1 \mathrm{cal} /(\mathrm{g} \mathrm{mole})(\mathrm{K})$.

The free energy of formation of $\mathrm{TaC}$ is given by Humphrey $(23)$ as $\Delta \mathrm{F}_{\mathrm{f} 298}=$ $-38.1 \pm 0.6 \mathrm{kcal}$ per $\mathrm{g}$ mole. This value was calculated from the data on heat of formation given above and the entropy value of Kelley (25) given below. The free energy of formation of $\mathrm{Ta}_{2} \mathrm{C}$ was calculated from the expression $\Delta \mathrm{F}=\Delta \mathrm{H}-\mathrm{T} \Delta \mathrm{S}$ to be $-36.4 \mathrm{kcal}$ per $g$ mole.

\section{Absolute Entropy}

According to Kelley $(25)$, the entropy of $\mathrm{TaC}$ is $\mathrm{S}_{\mathrm{f} 298}^{\circ}=10.11 \pm 0.08 \mathrm{cal} /(\mathrm{g} \mathrm{mole})$ (K). The entropy of $\mathrm{Ta}_{2} \mathrm{C}$, calculated from the value for entropy of formation given above, is $\mathrm{S}_{\mathrm{f} 298}^{\circ}=22.56 \mathrm{cal} /(\mathrm{g}$ mole $)(\mathrm{K})$.

\section{Heat Capacity}

Kelley $(25)$ gives the heat capacity of $\mathrm{TaC}$ as $\mathrm{C}_{\mathrm{p} 298}=8.79 \mathrm{cal} /(\mathrm{g} \mathrm{mole})(\mathrm{C})$.

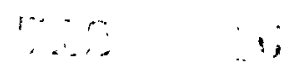



for TaC:

Kelley $(26)$ presents the following tabulation of low-temperature heat-capacity data

\begin{tabular}{|c|c|}
\hline $\begin{array}{l}\text { Temperature, } \\
\text { K }\end{array}$ & $\begin{array}{c}\mathrm{C}_{\mathrm{p}}, \\
\mathrm{cal} /(\mathrm{g} \text { mole })(\mathrm{C})\end{array}$ \\
\hline 54.6 & 2.275 \\
\hline 58.1 & 2.505 \\
\hline 62.1 & 2.759 \\
\hline 66.5 & 3.032 \\
\hline 71.1 & 3.298 \\
\hline 75.6 & 3.525 \\
\hline 80.2 & 3.735 \\
\hline 80.6 & 3.752 \\
\hline 84.4 & 3.903 \\
\hline 84.9 & 3.924 \\
\hline 94.5 & 4.271 \\
\hline 104.3 & 4. 583 \\
\hline 114.7 & 4. 876 \\
\hline 124.8 & 5.149 \\
\hline 134.8 & 5.415 \\
\hline 144.8 & 5.661 \\
\hline
\end{tabular}

\begin{tabular}{|c} 
Temperature \\
$\mathrm{K}$ \\
\hline 154.5 \\
164.6 \\
174.2 \\
184.5 \\
194.3 \\
204.5 \\
214.6 \\
224.5 \\
234.5 \\
244.7 \\
255.1 \\
265.3 \\
275.1 \\
284.6 \\
293.9 \\
294.5
\end{tabular}

\begin{tabular}{c}
$\mathrm{C}_{\mathrm{p}}$ \\
$\mathrm{cal} /(\mathrm{g}$ mole $)(\mathrm{C})$ \\
\hline 5.900 \\
6.141 \\
6.377 \\
6.614 \\
6.843 \\
7.078 \\
7.292 \\
7.514 \\
7.713 \\
7.912 \\
8.109 \\
8.280 \\
8.424 \\
8.559 \\
8.741 \\
8.764
\end{tabular}

\section{Enthalpy and Free Energy}

No tabulations are available in the literature; however, values can oe computed from the information given above.

Heat of Dissociation and Dissociation Constant

No tabulations are available in the literature; however, values can be computed from the information given above.

\section{Thermal Stability}

According to Brewer, et al. (6), both $\mathrm{TaC}$ and $\mathrm{Ta}_{2} \mathrm{C}$ are slowly volatile at $2500 \mathrm{~K}$ in high vacuum. A Fairchild report (4) states that tantalum carbide is nonvolatile at $2000 \mathrm{~K}(1727 \mathrm{C})$ and is slowly volatile at $2500 \mathrm{~K}(2227 \mathrm{C})$.

Ellinger(13) says that when $\mathrm{Ta}_{2} \mathrm{C}$ was heated to $3400 \mathrm{C}$, the specimens completely fused and then consisted of the TaC-C eutectic. Apparently the additional carbon was absorbed from the graphite crucible.

\section{Heat of Fusion and Heat of Transition}

No information is available in the literature. 
Physical Properties

$\underline{\text { Density }}$

McKenna(36) gives the density of $\mathrm{TaC}$ at room temperature as $14.49 \mathrm{~g}$ per $\mathrm{cm}^{3}$. According to Schwarzkopf and Kieffer (43), the density of $\mathrm{Ta} \mathrm{a}_{2} \mathrm{C}$ (calculated from the data given in the "Lattice Constants" section) is $15.22 \mathrm{~g}$ per $\mathrm{cm}^{3}$.

\section{Electrical and Magnetic Properties}

The electrical resistivity of $\mathrm{TaC}$ has been reported by several sources $(3,11,36)$ as being in the range of 17 to $30 \mathrm{microhm-cm}$ at room temperature.

Schwarzkopf and Kieffer (43) state that TaC becomes superconductive at $1.8 \mathrm{~K}$.

The magnetic susceptibility of $\mathrm{TaC}$ is given by Schwarzkopf and Kieffer (43) as less than $0.45 \times 10^{-6}$ at room temperature.

\section{Melting Point}

The best value for the melting point of $\mathrm{TaC}$ appears to be $3877 \pm 150 \mathrm{C}(1)$.

The melting point of $\mathrm{Ta}_{2} \mathrm{C}$ is given as $3400 \mathrm{C}(11)$.

\section{$\underline{\text { Boiling Point }}$}

The boiling point of $\mathrm{TaC}$ was given by Fairchild writers (4) as $5500 \mathrm{C}$ (determined by the electric-arc method).

\section{Structure}

$\mathrm{TaC}$ has a face-centered-cubic (Bl-type) structure $(11,12,36)$.

Ta ${ }_{2} \mathrm{C}$ has a hexagonal (L'3-type) structure (43).

\section{Lattice Constants}

The lattice constant for $\mathrm{TaC}$ is given by McKenna $(36)$ as $\mathrm{a}_{0}=4.445 \mathrm{~A}$. Schwarzkopf and Kieffer ${ }^{(43)}$ give the lattice constants of $\mathrm{Ta}_{2} \mathrm{C}$ as $\mathrm{a}_{0}=3.091 \pm 0.001 \mathrm{~A}$ and $c_{0}=4.93 \pm 0.007 \mathrm{~A}$.

\section{Phase Properties}

Figure 1 shows the phase diagram of the tantalum-carbon system as given by Ellinger(13). There are two eutectics in this system. The Ta-Ta $2 \mathrm{C}$ eutectic occurs at $0.6 \mathrm{w} / \mathrm{o}$ carbon and $2800 \mathrm{C}$, and the TaC-graphite eutectic occurs at approximately 


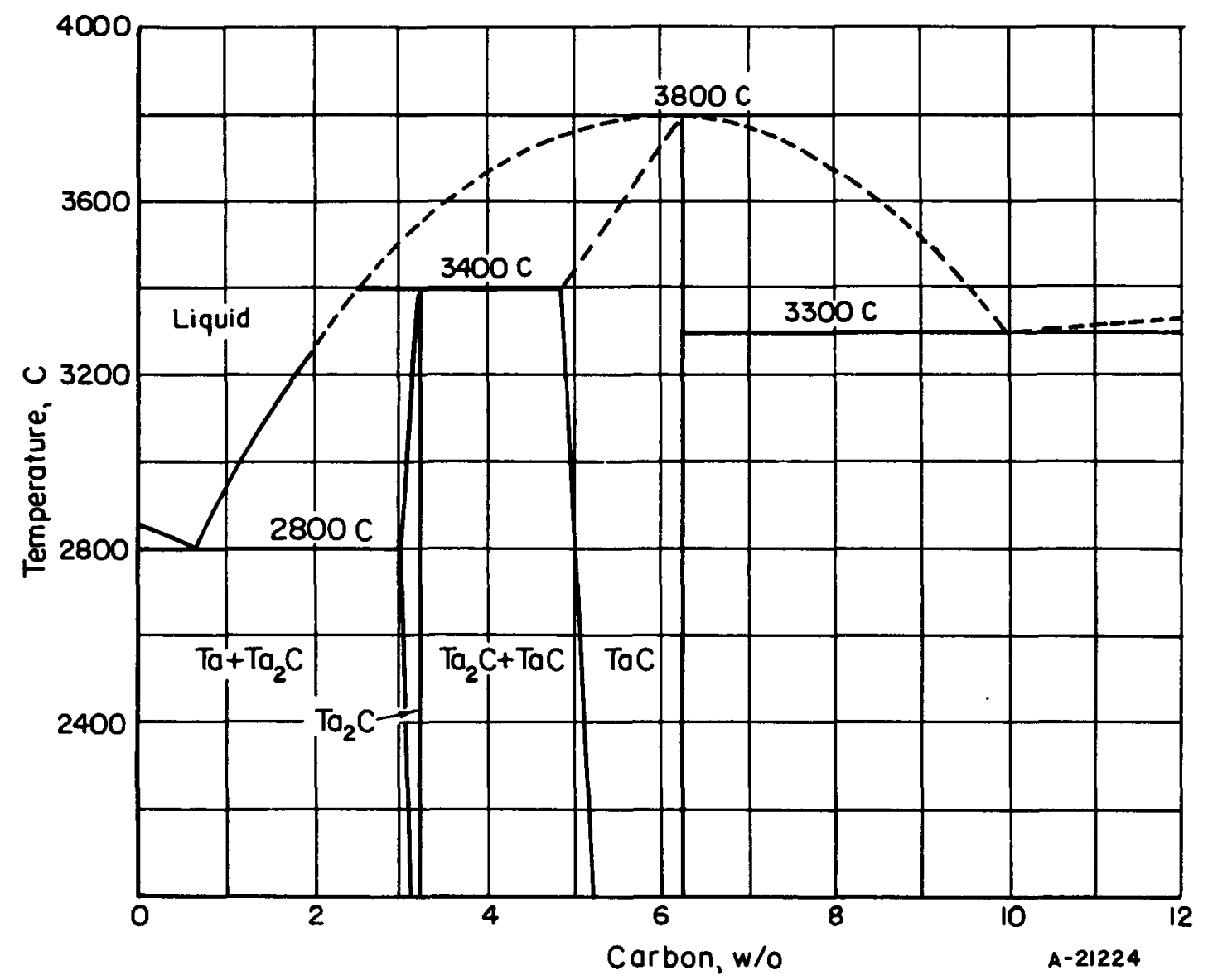

FIGURE 1. TENTATIVE CONSTITUTIONAL DIAGRAM OF TANTALUM-RICH END OF TANTALUM-CARBON SYSTEM 
$10 \mathrm{w} / 0$ carbon and $3300 \mathrm{C}$. Ellinger(13) states that $\mathrm{TaC}$ will dissolve up to $1.2 \mathrm{w} / \mathrm{o}$ of tantalum at $3400 \mathrm{C}$.

\section{Thermal Conductivity} $20 \mathrm{C}(11)$.

The thermal conductivity of $\mathrm{TaC}$ is given as $0.053 \mathrm{cal} /(\mathrm{sec})\left(\mathrm{cm}^{2}\right)(\mathrm{C} / \mathrm{cm})$ at

\section{Coefficient of Thermal Expansion}

The coefficient of thermal expansion of $\mathrm{TaC}$ is given as $8.2 \times 10^{-6}$ per $\operatorname{deg} C(11,14,43)$.

\section{Vapor Pressure}

No information is available in the literature.

\section{Emissivity}

Fairchild writers (4) state that the emissivity of $\mathrm{TaC}$ is higher than that of tungsten. Their graph of the thermal emission of $\mathrm{TaC}$ gives the following approximate values:

\begin{tabular}{cc} 
Temperature, C & Total Radiation, w per $\mathrm{cm}^{2}$ \\
\hline 1600 & 27 \\
1800 & 40 \\
2000 & 60 \\
2400 & 101 \\
2700 & 200
\end{tabular}

According to Campbell(11), the spectral emissivity of $\mathrm{TaC}$ coatings at $1820 \mathrm{C}$ is 0.67 at $\lambda=0.65 \mu$.

\section{Mechanical Properties}

\section{Tensile Strength}

Schwarzkopf and Kieffer (43) give the tensile strength of vapor-deposited $\mathrm{TaC}$ wire as 2000-4000 psi at room temperature. According to another source(4), TaC has a tensile strength of 2-3 $\mathrm{kg}$ per $\mathrm{mm}^{2}(2845-4267 \mathrm{psi})$ at room temperature.

\section{Compressive Strength, Creep, and}

\section{Rupture}

No information is available in the literature. 
Hardness

Mohs hardness of $\mathrm{TaC}=9+(11,20,43)$.

Brinell hardness of $\mathrm{TaC}=840(43)$.

Knoop (microhardness) of $\mathrm{TaC}=1800-2000(13,43)$.

Knoop (microhardness) of $\mathrm{Ta}_{2} \mathrm{C}=$ about $1000(13)$.

The temperature at which these measurements were taken was not specified. It is assumed to have been room temperature.

Modulus of Elasticity

The modulus of elasticity of $\mathrm{TaC}$ at room temperature is given by Schwarzkopf and Kieffer(43) as $29,500 \mathrm{~kg}$ per $\mathrm{mm}^{2}\left(41.5 \times 10^{6} \mathrm{psi}\right)$.

\section{General Properties}

Preparation, Fabrication, and Production Methods

According to Fairchild writers (4), TaC may be prepared from finely divided, intimately mixed tantalum oxide and carbon in an electric furnace. The reaction proceeds at a reasonable rate at about $1250 \mathrm{C}$. The product is $97-98 \mathrm{w} / 0$ carbide, the remainder being metal in solid solution in the carbide.

The Fairchild report(4) also describes a relatively new process for producing TaC which is carried out in molten aluminum. Tantalum and carbon are dissolved in molten aluminum, and the melt is heated in a graphite crucible to about $2000 \mathrm{C}$. After cooling, the solid is treated with acid which dissolves the aluminum and aluminum carbide, leaving $\mathrm{TaC}$ as gold-colored crystals.

Campbell(11) states that hot pressing, steel-die pressing, and sintering are satisfactory fabrication methods for $\mathrm{TaC}$. Hot pressing is satisfactory for $\mathrm{Ta}_{2} \mathrm{C}$.

\section{Toxicity}

No information is available in the literature.

\section{Availability}

Fairchild writers $(4)$ report that tantalum carbide is supplied by Fansteel Metallurgical Corporation. 
Data in the literature on resistance of $\mathrm{TiC}$ to reducing atmospheres at high temperatures and to thermal shock are incomplete. These are areas in which experimental work should be performed for all of the carbides reported.

\section{Chemical Properties}

\section{Composition}

The theoretical carbon content of $\mathrm{TiC}$ is $20.05 \mathrm{w} / \mathrm{o}$. However, since it forms a defect lattice in the composition range $\mathrm{TiC}_{0.65}$ to $\mathrm{TiC}_{1.0}$, it is difficult to prepare the pure stoichiometric compound.

\section{Corrosion and Compatibility}

According to Schwarzkopf and Kieffer (43), TiC is chemically very stable, and it is hardly attacked by hydrochloric or sulfuric acids. However, TiC is easily soluble in mixtures of $\mathrm{HNO}_{3}$ and $\mathrm{HF}$ and also dissolves in alkaline oxidizing melts. In atmospheres containing chlorine, $\mathrm{TiC}$ is attacked with the formation of the chloride or oxychloride.

\section{Erosion}

No information is available in the literature.

\section{Resistance to Oxidizing and/or Reducing}

Atmospheres

Pollard and Woodward(38) state that $\mathrm{TiC}$ is oxidized rapidly in the presence of oxygen, $\mathrm{N}_{2} \mathrm{O}$, or $\mathrm{CO}_{2}$ at $1200 \mathrm{C}$, but it does not react with nitrogen, hydrogen, or $\mathrm{CO}$ at this temperature. The reactions of $\mathrm{TiC}$ with $\mathrm{N}_{2} \mathrm{O}$ and $\mathrm{CO}_{2}$ are both first order.

\section{Physical-Chemical Properties}

Heat, Entropy, and Free Energy of

\section{Formation}

The heat of formation of $\mathrm{TiC}$ is given as $\Delta \mathrm{H}_{\mathrm{f} 298}^{\circ}=-43.8 \mathrm{kcal}$ per $\mathrm{g}$ mole by Humphrey (22). This value was calculated by Humphrey from his experimental data on heat of combustion.

The free energy of formation of $\mathrm{TiC}$ is given by Humphrey (22) as $\Delta \mathrm{F}_{\mathrm{f} 298}^{\circ}=$ $-43.0 \mathrm{kcal}$ per $\mathrm{g}$ mole. This value was calculated from the value for heat of formation 
given above, the absolute entropy value for $\mathrm{TiC}$ of Kelley (25) given below, and the absolute entropies of titanium and carbon given by Rossini, et al. (41).

The entropy of formation, calculated from the absolute entropy for TiC of

Kelley $(25)$ and the absolute entropies of titanium and carbon given by Rossini, et al. (4l), is $\Delta \mathrm{S}_{\mathrm{f} 298}^{\circ}=-2.8 \mathrm{cal} /(\mathrm{g} \mathrm{mole})(\mathrm{K})$.

\section{Absolute Entropy}

Kelley ${ }^{(25)}$ recommends a value for the entropy of $\mathrm{TiC}$ of $\mathrm{S}_{298}^{\circ}=5.79 \pm 0.05 \mathrm{cal} /$ (g mole)(K).

\section{Entropy and Enthalpy}

The following tabulation gives the heat content and entropy of $\mathrm{TiC}$ as functions of temperature, Kelley $(24)$.

\begin{tabular}{|c|c|c|}
\hline $\begin{array}{c}\text { Temperature, } \\
\mathrm{K}\end{array}$ & $\begin{array}{l}\mathrm{H}_{\mathrm{T}}{ }^{-\mathrm{H}_{298,16}} \\
\text { cal per } \mathrm{g} \text { mole }\end{array}$ & $\begin{array}{c}\mathrm{S}_{\mathrm{T}}-\mathrm{S}_{298.16} \\
\mathrm{cal} /(\mathrm{g} \text { mole })(\mathrm{K})\end{array}$ \\
\hline 400 & 945 & 2.72 \\
\hline 500 & 1,975 & 5.01 \\
\hline 600 & 3,085 & 7.03 \\
\hline 700 & 4,225 & 8.79 \\
\hline 800 & 5,395 & 10.35 \\
\hline 900 & 6,600 & 11.77 \\
\hline 1000 & 7,830 & 13.07 \\
\hline 1100 & 9,080 & 14.26 \\
\hline
\end{tabular}

\begin{tabular}{|c|c|c|}
\hline $\begin{array}{c}\text { Temperature, } \\
\mathrm{K}\end{array}$ & $\begin{array}{r}\mathrm{H}_{\mathrm{T}}-\mathrm{H}_{298.16} \\
\text { cal per } \mathrm{g} \text { mole } \\
\end{array}$ & $\begin{array}{c}\mathrm{S}_{\mathrm{T}}-\mathrm{S}_{298.16} \\
\mathrm{cal} /(\mathrm{g} \text { mole })(\mathrm{K})\end{array}$ \\
\hline 1200 & 10,330 & 15.35 \\
\hline 1300 & 11,590 & 16.35 \\
\hline 1400 & 12,860 & 17.29 \\
\hline 1500 & 14,130 & 18.17 \\
\hline 1600 & 15,400 & 18.99 \\
\hline 1700 & 16,670 & 19.76 \\
\hline 1800 & 17,940 & 20.49 \\
\hline
\end{tabular}

\section{Heat Capacity}

Kelley ${ }^{(25)}$ presents the following tabulation of the heat capacity of $\mathrm{TiC}$ at low temperatures:

Heat Capacity, cal/(g mole)(K)

\begin{tabular}{lllllll}
\hline $10 \mathrm{~K}$ & $\frac{25 \mathrm{~K}}{(0.00)}$ & $\frac{50 \mathrm{~K}}{(0.04)}$ & $\frac{100 \mathrm{~K}}{0.23}$ & $\frac{150 \mathrm{~K}}{1.75}$ & $\frac{200 \mathrm{~K}}{3.76}$ & $\frac{298.16 \mathrm{~K}}{5.57}$
\end{tabular}

\section{Free Energy}

No tabulations are available in the literature; however, free-energy values for TiC can be calculated from the data given above.

\section{Thermal Stability}

According to Brewer, et al. (6), TiC is slowly volatile at $2500 \mathrm{~K}$ in a high vacuum. 
Heat of Fusion and Heat of Transition

No information is available in the literature.

\section{Physical Properties}

\section{Density}

The calculated X-ray density of $\mathrm{TiC}$ at room temperature is given by Glaser and Ivanick (17) as $4.93 \mathrm{~g}$ per $\mathrm{cm}^{3}$.

\section{Electrical and Magnetic Properties}

Glaser and Ivanick(17) give the electrical resistivity at room temperature of pressure-sintered $\mathrm{TiC}$ as a function of the particle size of the TiC powder used:

\begin{tabular}{cc}
$\begin{array}{c}\text { Particle Size, } \\
\mu\end{array}$ & $\begin{array}{c}\text { Electrical Resistivity, } \\
\mu \text { ohm-cm }\end{array}$ \\
\hline$<74$ to $>44$ & 78.3 \\
$<44$ to $>37$ & 72.0 \\
$<37$ to $>8$ & 72.1 \\
$<8$ to $>2$ & 68.2
\end{tabular}

According to Schwarzkopf and Kieffer(43), TiC is superconducting at $1.15 \mathrm{~K}$.

The magnetic susceptibility of TiC at room temperature is given by Schwarzkopf and Kieffer ${ }^{(43)}$ as $0.12 \times 10^{-6} \mathrm{cgs-emu.}$

\section{Melting Point}

According to Agte and Moers(2), the melting point of TiC is $3140 \mathrm{C}$.

\section{Boiling Point}

The boiling point of $\mathrm{TiC}$ is $4300 \mathrm{C}(43)$.

\section{Molecular Structure}

TiC has a face-centered-cubic NaCl-type structure(11).

\section{Lattice Constants}

The lattice constant for $\mathrm{TiC}$ is given as $\mathrm{a}_{0}=4.32 \mathrm{~A}(43)$. 


\section{Phase Changes}

A phase diagram of the titanium-carbon system given by Cadoff and Nielsen $(10)$ is shown in Figure 2 .

\section{Thermal Conductivity}

A tabulation of the thermal conductivity of $\mathrm{TiC}$ as a function of temperature is given by Wood $(47)$.

\begin{tabular}{cc}
$\begin{array}{c}\text { Temperature, } \\
\mathrm{K}\end{array}$ & $\begin{array}{c}\text { Thermal Conductivity, } \\
\mathrm{cal} /(\mathrm{sec})\left(\mathrm{cm}^{2}\right)(\mathrm{C} / \mathrm{cm})\end{array}$ \\
\hline 20 & 0.075 \\
500 & 0.025 \\
1000 & 0.014
\end{tabular}

The thermal conductivity of $\mathrm{TiC}$ at room temperature is given as $0.041 \mathrm{cal} /(\mathrm{sec})$ $\left(\mathrm{cm}^{2}\right)(\mathrm{C} / \mathrm{cm})^{(43)}$.

\section{Coefficient of Thermal Expansion}

According to Campbell(11), the coefficient of linear expansion of $\mathrm{TiC}$ is $7.4 \times 10^{-6}$ per $C(25$ to $800 \mathrm{C})$.

\section{Vapor Pressure}

According to Brewer, et al. (6), the vapor pressure of $\mathrm{TiC}$ is less than $10-7 \mathrm{~atm}$ at $2500 \mathrm{~K}$.

\section{Emissivity}

According to Campbell(11), the emissivity of $\mathrm{TiC}$ at $1820 \mathrm{C}$ is 0.96 at $\lambda=0.65 \mu$.

\section{Mechanical Properties}

\section{Compressive Strength}

The compressive strength of $\mathrm{TiC}$ is given by Campbell(11) as 190,000 psi at room temperature.

\section{Tensile Properties} et al. (15).

A tabulation of the tensile strength of $\mathrm{TiC}$ at $980 \mathrm{C}$ and $1200 \mathrm{C}$ is given by Gangler, 


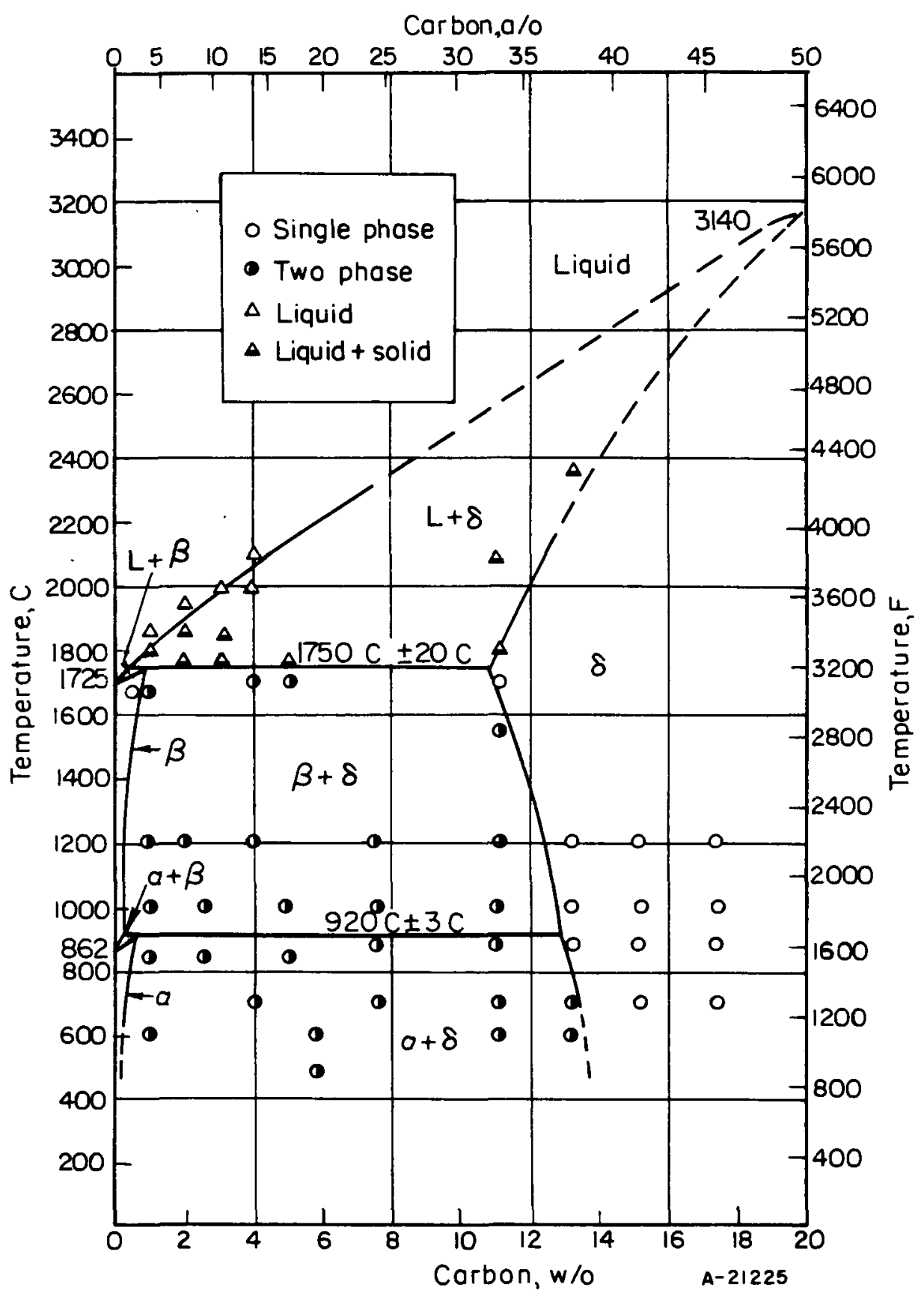

FIGURE 2. TITANIUM-CARBON PHASE DIAGRAM

Reprinted from Cadoff and Nielson(10). 


\begin{tabular}{|c|c|c|c|}
\hline Soaking Temperature, & Soaking Time, & Tensile & gth, psi \\
\hline $\mathrm{C}$ & $h \mathbf{r}$ & $980 \mathrm{C}$ & $1200 \mathrm{C}$ \\
\hline 1040 & $13-1 / 2$ & 15,850 & -- \\
\hline 1040 & 4 & 17,200 & -- \\
\hline 1260 & 5 & -- & 8000 \\
\hline 1260 & Unknown & -- & 9400 \\
\hline
\end{tabular}

\section{Creep}

No information is available in the literature.

\section{$\underline{\text { Rupture }}$}

Glaser and Ivanick(17) give values of the transverse rupture strength at room temperature of pressure-sintered $\mathrm{TiC}$ as a function of the particle size of the TiC powder used:

\begin{tabular}{cc}
$\begin{array}{c}\text { Particle Size, } \\
\mu\end{array}$ & $\begin{array}{c}\text { Transverse Rupture Strength, } \\
\text { psi }\end{array}$ \\
\cline { 2 - 2 }$<44$ to $>44$ & 73,500 \\
$<44$ to $>37$ & 91,000 \\
$<37$ to $>8$ & 100,000 \\
$<8$ to $>2$ & 124,000
\end{tabular}

\section{$\underline{\text { Hardness* }}$}

Mohs hardness $=9$ to $10(43)$.

Microhardness $=3200 \mathrm{~kg}$ per $\mathrm{mm}^{(43)}$.

Rockwell A hardness of sintered TiC as a function of the TiC powder particle size is given by Glaser and Ivanick $(17)$ as:

Particle Size,

\begin{tabular}{l}
$\mu$ \\
\hline$<74$ to $>44$ \\
$<44$ to $>37$ \\
$<37$ to $>8$ \\
$<8$ to $>2$
\end{tabular}

\begin{tabular}{c} 
Rockwell A Hardness \\
\hline $\mathbf{8 8}-89$ \\
$\mathbf{8 8}-89$ \\
$91-92$ \\
$92.5-93.5$
\end{tabular}

\section{Modulus of Elasticity}

According to Schwarzkopf and Kieffer (43), the modulus of elasticity of TiC at room temperature is $32,200 \mathrm{~kg}$ per $\mathrm{mm}^{2}\left(45 \times 10^{6} \mathrm{psi}\right)$.

* The hardness data are assumed to be room-temperature values. 


\section{General Properties}

Preparation, Fabrication, and

Production Methods

Campbell(11) states that the stoichiometric monocarbide of TiC can be produced by the McKenna process in which the metal or metal oxide is reacted with carbon in a molten metallic menstruum at 1800-2000 C. Pure TiC microcrystals remain after the impurities are removed by acid leaching and gravity separation.

According to Campbell(11), hot pressing, steel-die pressing, and sintering are satisfactory methods of fabricating TiC.

Glaser and Ivanick(17) produced the dense, binder-free TiC bodies referred to in previous sections by using a high-temperature and pressure sintering procedure in which the TiC powder was sintered at $3000 \mathrm{C}$ for approximately 30 sec under a constant pressure of about 1.3 ton per in. ${ }^{2}$.

\section{PROPERTIES OF BERYLLIUM OXIDE}

Like all ceramic bodies, BeO ceramics are brittle at ordinary temperatures. Fracture occurs without plastic deformation, and the useful strength is limited by the occurrence of flaws or local stress risers at which fracture is initiated. The useful strength is determined by the kind and number of flaws, and these, in turn, are influenced by crystal size and structure, as well as by the shape and size of the ceramic. For this reason, strength data on ceramics show a characteristically wide scatter even for specimens having the same size and history.

Attempts to increase the useful strength of polycrystalline ceramics have been directed toward limiting the size and frequency of flaws by decreasing the porosity and crystal size. Recent experiments by Hyde, et al. (21), along this line have resulted in BeO ceramics having about twice the strength previously reported for them.

The strength of $\mathrm{BeO}$ ceramics decreases markedly at temperatures above $1000 \mathrm{C}$ and creep becomes an important consideration.

Resistance to thermal stress is probably higher for BeO than for any other ceramics except graphite or silicon carbide. One study $(5)$ indicated that maximum heat transfer through $\mathrm{BeO}$ ceramics was approximately twice that required to fracture alumina.

In general, the properties of BeO ceramics are not improved by addition of other oxides. One investigation(16) showed that thermal conductivity and electrical resistivity of $\mathrm{BeO}$ were decreased by addition of other refractory oxides. Compressive strength was either unaffected or decreased. 


\section{Chemical Properties}

\section{Composition}

The compositions of typical commercial beryllia powders are given by Norton(37).

\begin{tabular}{|c|c|c|c|}
\hline & & Analysis, w/o & \\
\hline & Light Fluffy $(a)$ & $\begin{array}{c}\text { High-Fire } \\
\text { Standard Purity }(a)\end{array}$ & $\begin{array}{l}\text { Refractory } \\
\text { Grade(b) }\end{array}$ \\
\hline $\mathrm{BeO}$ & $\frac{9}{99.8}$ & 99.8 & 99.3 \\
\hline $\mathrm{SiO}_{2}$ & & 0.09 & 0.22 \\
\hline $\mathrm{Al}_{2} \mathrm{O}_{3}$ & 0.01 & 0.01 & 0.22 \\
\hline $\mathrm{Fe}_{2} \mathrm{O}_{3}$ & 0.10 & 0.10 & 0.07 \\
\hline $\mathrm{MgO}$ & 0.02 & 0.02 & 0.12 \\
\hline $\mathrm{CaO}$ & 0.02 & 0.02 & 0.02 \\
\hline $\mathrm{MnO}$ & & & 0.005 \\
\hline Alkalies & 0.02 & & \\
\hline
\end{tabular}

(a) Brush Beryllium Company.

(b) Clifton Products Company.

\section{Corrosion}

Quantitative data on the chemical reactivity and corrosion of $\mathrm{BeO}$ are sparse and often contradictory, due largely to the difficulty of standardizing and reporting the area of reacting surface and other test conditions. Densely sintered BeO ceramics are stable toward most materials except $\mathrm{HF}$, fused alkalies, and water vapor at high temperatures. Finely divided $\mathrm{BeO}$ powder is dissolved readily by fused alkalies, alkaline carbonates, and pyrosulfates, and more slowly by solutions of alkalies or mineral acids. BeO is the most resistant of the refractory oxides to high-temperature reaction with carbon; the minimum reaction temperature, in vacuum, between bulk graphite and dense $\mathrm{BeO}$ is reported as $2300 \mathrm{C}$. High-temperature reactions have been observed between $\mathrm{BeO}$ and beryllium, calcium, magnesium, niobium, silicon, titanium, zirconium, and uranium. Dense $\mathrm{BeO}$ is reported to be resistant to molten lead, lithium, potassium and sodium at $800 \mathrm{C}$ and molten calcium at $600 \mathrm{C}$.

\section{Erosion}

No information is available in the literature.

Resistance to Oxidizing and/or Reducing

Atmospheres

$\mathrm{BeO}$ is not attacked by $\mathrm{H}_{2} \mathrm{O}_{2}$, hydrogen, nitrogen, $\mathrm{CO}_{2}$, ammonia or $\mathrm{CO}$. The reaction of $\mathrm{BeO}$ with $\mathrm{H}_{2} \mathrm{O}$ at temperatures above $1000 \mathrm{C}$ produces the volatile compound $\mathrm{Be}(\mathrm{OH})_{2}$ according to Livey and Murray (32). 
Heat, Entropy, and Free Energy of

Formation

According to White and Burke(46), the heat of formation of $\mathrm{BeO}$ is $\Delta \mathrm{H}_{\mathrm{f} 298}=-147,000 \pm 5,000 \mathrm{cal}$ per $\mathrm{g}$ mole, the entropy of formation is $\Delta \mathrm{S}_{\mathrm{f} 298}^{\circ}=$ $23.4 \mathrm{cal} /(\mathrm{g} \mathrm{mole})(\mathrm{K})$, and the free energy of formation is $\Delta \mathrm{F}_{\mathrm{f} 298}^{\circ}=-140,000 \mathrm{cal}$ per $\mathrm{g}$ mole.

Heat and Entropy of Fusion

Long and Schofield (33) give the heat of fusion of $\mathrm{BeO}$ as $\Delta \mathrm{H}_{\text {fus }}^{\circ}=17,000 \pm$ $1400 \mathrm{cal}$ per $\mathrm{g}$ mole and the entropy of fusion as $\Delta S_{\mathrm{fus}}^{\circ}=6.0 \pm 0.5 \mathrm{cal} /(\mathrm{g} \mathrm{mole})(\mathrm{K})$.

Heat and Entropy of Vaporization

Long and Schofield(33) give a value for the heat of vaporization of $\mathrm{BeO}$ of $\Delta \mathrm{H}_{\mathrm{vap}}^{\circ}=117,000 \pm 10,500 \mathrm{cal}$ per $\mathrm{g}$ mole, and a value for the entropy of vaporization of $\Delta \mathrm{S}_{\mathrm{vap}}^{\circ}=25.8 \pm 2.3 \mathrm{cal} /(\mathrm{g}$ mole $)(\mathrm{K})$.

\section{Heat of Sublimation}

The heat of sublimation of $\mathrm{BeO}$ is given as $\Delta \mathrm{H}_{\mathrm{sub}}^{\circ}=152,000 \pm 10,000$ cal per $\mathrm{g}$ mole $(600$ to $3000 \mathrm{C})$ by Long and Schofield(33).

Entropy, Enthalpy, and Free Energy

A table of the heat content, entropy, and free energy function of $\mathrm{BeO}$ is given by White and Burke(46).

\section{Heat Capacity}

A graph of the heat capacity of $\mathrm{BeO}$ is given by White and Burke(46).

\section{Physical Properties}

$\underline{\text { Density }}$

White ${ }^{(46)}$ gives the theoretical density of $\mathrm{BeO}$ as $3.025 \mathrm{~g} / \mathrm{cc}$. 


\section{Electrical and Magnetic Properties}

White and Burke(46) give the following data for the electrical resistivity of beryllia (density $=2.25 \mathrm{~g}$ per $\mathrm{cm}^{3}$ ) sintered at $2100 \mathrm{C}$ and measured in nitrogen atmosphere:

\begin{tabular}{cr|cc}
$\begin{array}{c}\text { Temperature, } \\
C\end{array}$ & $\begin{array}{c}\text { Resistivity, } \\
\text { ohm-cm }\end{array}$ & $\begin{array}{r}\text { Temperature, } \\
\text { C }\end{array}$ & $\begin{array}{c}\text { Resistivity, } \\
\text { ohm-cm }\end{array}$ \\
\cline { 1 - 1 } & $\begin{array}{c}\text { 80,000,000 } \\
1000\end{array}$ & 1800 & 6500 \\
1200 & $4,000,000$ & 2000 & 1600 \\
1400 & 250,000 & 2100 & 800 \\
1600 & 35,000 & &
\end{tabular}

The magnetic susceptibility of $\mathrm{BeO}$ is given by White and Burke(46) as $-0.477 \times 10^{-6} \mathrm{cgs}-\mathrm{emu}$ per $\mathrm{g}$ at room temperature.

Melting Point

According to Long and Schofield(33), the melting point of $\mathrm{BeO}$ is $2550 \pm 25 \mathrm{C}$.

\section{Boiling Point}

Long and Schofield ${ }^{(33)}$ give the boiling point of $\mathrm{BeO}$ as $4260 \mathrm{C}$.

\section{Structure}

BeO has a hexagonal (zincite type) structure, according to White and Burke ${ }^{(46)}$.

\section{Lattice Constants}

According to Long and Schofield(33), the lattice constants of $\mathrm{BeO}$ are $\mathrm{a}_{0}=2.69 \mathrm{~A}$ and $c_{0}=4.39 \mathrm{~A}$.

\section{Phase Properties}

The reactions of $\mathrm{BeO}$ with other oxides are usually reported in the form of phase equilibrium diagrams. Partial or complete diagrams for $\mathrm{BeO}$ with the following have been compiled by Levin, et al. (31):

$\mathrm{Al}_{2} \mathrm{O}_{3}, \mathrm{CaO}, \mathrm{CoO}, \mathrm{Cu}_{2} \mathrm{O}, \mathrm{Cr}_{2} \mathrm{O}_{3}, \mathrm{Fe}_{3} \mathrm{O}_{4}, \mathrm{La}_{2} \mathrm{O}_{3}, \mathrm{MgO}, \mathrm{NiO}, \mathrm{SiO}_{2}, \mathrm{Mn}_{3} \mathrm{O}_{4}$, $\mathrm{CeO}_{2}, \mathrm{TiO}_{2}, \mathrm{ThO}_{2}, \mathrm{ZrO}_{2}, \mathrm{Al}_{2} \mathrm{O}_{3}-\mathrm{MgO}, \mathrm{Al}_{2} \mathrm{O}_{3}-\mathrm{ThO}_{2}, \mathrm{Al}_{2} \mathrm{O}_{3}-\mathrm{TiO}_{2}, \mathrm{Al}_{2} \mathrm{O}_{3}-\mathrm{ZrO}_{2}$, $\mathrm{CaO}-\mathrm{ZrO}_{2}, \mathrm{CeO}_{2}-\mathrm{ZrO}_{2}, \mathrm{Cr}_{2} \mathrm{O}_{3}-\mathrm{ZrO}_{2}, \mathrm{MgO}-\mathrm{ThO}_{2}, \mathrm{MgO}-\mathrm{ZrO}_{2}, \mathrm{TiO}_{2}-\mathrm{Z} \mathrm{rO}_{2}$, and $\mathrm{Al}_{2} \mathrm{O}_{3}-\mathrm{CaO}$.

Data are also given on the system BeO-BaO by Geller, et al. (16), and on the system $\mathrm{BeO}-\mathrm{UO}_{2}$ by Lang, et al. (30). 
It is of interest that in the system $\mathrm{BeO}-\mathrm{UO}_{2}$ there are reportedly no compounds, solid solubilities, nor any other solid-state reactions at temperatures from 800 to $1800 \mathrm{C}$ within the range from 10 to 90 mole per cent $\mathrm{UO}_{2}$.

\section{Thermal Conductivity}

The thermal conductivity of $\mathrm{BeO}$ is given by White and Burke (46) as 0.4 $\mathrm{cal} /(\mathrm{sec})\left(\mathrm{cm}^{2}\right)(\mathrm{C} / \mathrm{cm})$ at $204 \mathrm{C}$.

\section{Coefficient of Thermal Expansion}

The coefficient of thermal expansion of $\mathrm{BeO}$ is $10.8 \times 10^{-6}$ per deg $\mathrm{C}$, according to Long and Schofield(33).

\section{Vapor Pressure}

The vapor pressure of $\mathrm{BeO}$ is $10^{-6}$ atm at $1930 \mathrm{C}$, according to White and Burke ${ }^{(46)}$. BeO vaporizes exclusively to beryllium and oxygen atoms.

\section{Emissivity}

White and Burke(46) give the total emissivity of $\mathrm{BeO}$ as being in the range of 0.4 at $1150 \mathrm{C}$.

\section{Mechanical Properties}

\section{Tensile Strength}

White and Burke(46) give a room-temperature value for the tensile strength of $\mathrm{BeO}$ of 18,500 psi.

\section{Compressive Strength}

White and Burke ${ }^{(46)}$ report the room-temperature compressive strength of $\mathrm{BeO}$ as being in excess of 200,000 psi for the material at or near theoretical density.

\section{Hardness}

According to White and Burke(46), BeO has a hardness value of 9 on the Mohs scale. 
Modulus of Elasticity

Campbell(11) gives a value for the modulus of elasticity of $\mathrm{BeO}$ of $55 \times 10^{6} \mathrm{psi}$ at room temperature.

\section{General Properties}

Preparation, Fabrication, and Production

Methods

The preparation, fabrication, and production methods for $\mathrm{BeO}$ are given by Long and Schofield(33), White and Burke(46), Campbell(11), and Green and Stewart(18).

\section{$\underline{\text { Toxicity }}$}

Beryllium and certain of its compounds are extremely toxic materials and can produce a variety of toxic manifestations in humans. White and Burke(46) state that the toxicity of beryllium oxide is variable depending considerably on the calcining temperature. Oxides produced at above approximately $1540 \mathrm{C}$ apparently are not acutely toxic. The mechanism of beryllia poisoning is not completely understood, but enough information is available to make it possible to handle the material safely by using the proper precautions.

\section{PROPERTIES OF BERYLLIUM CARBIDE}

$\mathrm{Be}_{2} \mathrm{C}$, the only compound in the beryllium-carbon system, dissociates without melting at about $2150 \mathrm{C}$. The relatively high vapor pressure (reportedly about $5 \mathrm{~mm}$ of mercury at $1630 \mathrm{C}$ ) interferes with the fabrication of dense shapes by sintering at normal pressures and is an important factor limiting the usefulness of $\mathrm{Be}_{2} \mathrm{C}$ as a refractory. Hot pressing and the use of fluxing additives are reported to be effective for fabricating dense $\mathrm{Be}_{2} \mathrm{C}$ shapes at temperatures below $1650 \mathrm{C}$. Addition of $2.5 \mathrm{w} / \mathrm{o} \mathrm{UC}_{2}$ appeared to promote sintering without causing any major change in the properties of sintered compacts.

Very limited experimental data indicate that the thermal-shock resistance of $\mathrm{Be}_{2} \mathrm{C}$ ceramics is poor. Considerations of strength, thermal conductivity, thermal expansion, and other properties also would indicate rather low resistance to heat shock involving guench temperatures below about $1000 \mathrm{C}$. No data are available for higher temperatures.

\section{Chemical Properties}

\section{Corrosion}

According to Norton(37), $\mathrm{Be}_{2} \mathrm{C}$ decomposes in $\mathrm{H}_{2} \mathrm{O}$ and is soluble in acids.

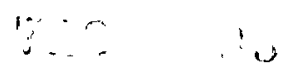




\section{Erosion}

Experiments by Harman and $O^{\prime}$ Bannon(19) to determine rates of erosion in combustion-product gas at $1370 \mathrm{C}$ and $\mathrm{Mach} 1.0$ indicate that attack on porous sintered compacts occurred rather rapidly in the wake of oxidation. Data on erosion in nonoxidizing gases are not available.

\section{Resistance to Oxidizing and/or Reducing}

Atmospheres

Beryllium carbide is quite reactive. It is hydrolyzed by water vapor at room temperature and reacts readily with oxygen, nitrogen, or ammonia above about $1000 \mathrm{C}$. The oxide and nitride products of these reactions are generally nonprotective. The rates of attack depend, of course, on the effective exposed area and become fairly low for densely sintered compacts. Oxidation rates in hot air appear to be about ten times higher than for silicon carbide under similar test conditions. Siliceous ceramic coatings were found to reduce the oxidation rate of sintered $\mathrm{Be}_{2} \mathrm{C}$ compacts in air at temperatures up to $1370 \mathrm{C}$.

\section{Physical-Chemical Properties}

Heat, Entropy, and Free Energy of Formation

The free energy of formation of $B e_{2} \mathrm{C}$ is given by Quirk $(40)$ as $\Delta \mathrm{F}_{\mathrm{f} 2400}^{\circ}=$ $-7.83 \mathrm{kcal}$ per $\mathrm{g}$ mole. Krikorian $(27)$ gives values for the heat, entropy, and free energy of formation of $\mathrm{Be}_{2} \mathrm{C}$ as $\Delta \mathrm{H}_{\mathrm{f} 298}^{\circ}=-13 \pm 5 \mathrm{kcal} /$ equiv., $\Delta \mathrm{S}_{\mathrm{f} 298}^{\circ}=-2.0 \pm 1.0$ $\mathrm{cal} /$ (equiv. $(\mathrm{K})$, and $\Delta \mathrm{F}_{\mathrm{f} 298}^{\circ}=-12.4 \pm 5 \mathrm{kcal} / \mathrm{equiv}$, respectively.

\section{Heat Capacity}

The heat capacity of $\mathrm{Be}_{2} \mathrm{C}$ is given by Quirk (40) as $0.334 \pm 0.013 \mathrm{cal} /(\mathrm{g})(\mathrm{C})$ (30 to $100 \mathrm{C})$ for $98 \mathrm{w} / 0 \mathrm{Be}_{2} \mathrm{C}$.

\section{Physical Properties}

Density

Quirk (40) gives the calculated X-ray density of $\mathrm{Be}_{2} \mathrm{C}$ as $2.44 \mathrm{~g}$ per $\mathrm{cm}^{3}$.

\section{Electrical and Magnetic Properties}

Quirk (40) gives an electrical-resistivity value of $0.063 \mathrm{ohm}-\mathrm{cm}(30 \mathrm{C})$ for impure sintered $\mathrm{Be}_{2} \mathrm{C}$ compacts and a value of $1.09 \mathrm{ohm}-\mathrm{cm}(65 \mathrm{C})$ for hot-pressed $\mathrm{Be}_{2} \mathrm{C}$ compacts. Electrical properties of pure $\mathrm{Be}_{2} \mathrm{C}$ have not been reported. 


\section{Melting Point}

Quirk $(40)$ states that $\mathrm{Be}_{2} \mathrm{C}$ dissociates, with rapid vaporization of beryllium, when heated in argon at atmospheric pressure to about $2150 \mathrm{C}$.

\section{Structure}

According to Quirk (40), $\mathrm{Be}_{2} \mathrm{C}$ has a cubic antifluorite-type structure.

\section{Lattice Constants}

Quirk (40) gives the lattice constant of $\mathrm{Be}_{2} \mathrm{C}$ as $\mathrm{a}_{0}=4.344 \mathrm{~A}$.

\section{Thermal Conductivity}

The thermal conductivity of $\mathrm{Be}_{2} \mathrm{C}$ is given by $\mathrm{Campbell}(11)$ as $0.05 \mathrm{cal} /$ $(\mathrm{sec})\left(\mathrm{cm}^{2}\right)(\mathrm{C} / \mathrm{cm})(20-425 \mathrm{C})$.

\section{Coefficient of Thermal Expansion} $\mathrm{Be}_{2} \mathrm{C}$ :

Quirk $(40)$ gives the following values for the coefficient of thermal expansion of

\begin{tabular}{cc}
$\begin{array}{c}\text { Temperature, } \\
\text { C }\end{array}$ & $\begin{array}{c}\text { Coefficient of Thermal Expansion, } \\
\text { per deg C }\end{array}$ \\
\cline { 2 - 2 } 25 to 50 & $5.6 \times 10^{-6}$ \\
25 to 200 & $7.7 \times 10^{-6}$ \\
25 to 400 & $9.5 \times 10^{-6}$ \\
25 to 600 & $10.5 \times 10^{-6}$
\end{tabular}

\section{Vapor Pressure}

The following data on the variation of vapor pressure with temperature for $\mathrm{Be}_{2} \mathrm{C}$ are given by Quirk (40) (vaporization occurs by decomposition to beryllium vapor and solid carbon; the dissociation is rapid at $2150 \mathrm{C}$ ):

\begin{tabular}{c} 
Temperature, \\
\hline 1627 \\
1827 \\
2127 \\
2327
\end{tabular}

\begin{tabular}{l}
$\begin{array}{l}\text { Vapor Pressure, } \\
\text { atm }\end{array}$ \\
\hline $\begin{array}{l}6 \times 10^{-3} \\
4 \times 10^{-2} \\
0.44 \\
1.5\end{array}$
\end{tabular}




\section{Mechanical Properties}

Compressive Strength

White and Burke ${ }^{(46)}$ give the compressive strength of hot-pressed $\mathrm{Be}_{2} \mathrm{C}$ as 105,000 psi at room temperature.

Modulus of Elasticity

According to White and Burke $(46)$, the modulus of elasticity of hot-pressed $\mathrm{Be}_{2} \mathrm{C}$ is $45.6 \times 10^{6} \mathrm{psi}$ at $0 \mathrm{C}$.

Poisson's Ratio

White and Burke ${ }^{(46)}$ give Poisson's ratio for hot-pressed $\mathrm{Be}_{2} \mathrm{C}$ as 0.10.

Hardness

According to Campbell(11), the Mohs hardness of $\mathrm{Be}_{2} \mathrm{C}$ is $9+$.

\section{General Properties}

Preparation, Fabrication, and

Production Methods

White and Burke(46) describe two basic reactions by which beryllium carbide is produced. The first is a solid or liquid phase reaction with beryllium and carbon, and the second is the reduction of beryllium oxide with carbon.

Campbell(11) gives the satisfactory methods of fabrication for $\mathrm{Be}_{2} \mathrm{C}$ as hot pressing, steel-die pressing and sintering, hydrostatic pressing, and sintering.

\section{$\underline{\text { Toxicity }}$}

The toxicity of beryllium carbide is not known precisely, but it is assumed to be of the same order as that of beryllium oxide. 


\section{BIBLIOGRAPHY}

(1) Agte, C., and Alterthum, H., "Systems of High-Melting Carbides; Contributions to the Problem of Carbon Fusion", Z. Tech. Physik, 11, 182 (1930).

(2) Agte, C., and Moers, K., "Methods for the Preparation of Pure High-Melting Carbides, Nitrides and Borides and a Description of a Few of Their Properties", Z. anorg. u. allgem. Chem., 198, 233 (1931).

(3) Andrews, M. R., "Reaction of Gases With Incandescent Tantalum", J. Am. Chem. Soc., 54, 1845 (1932).

(4) Anon., "Report on Tantalum Carbide", Fairchild Engine and Airplane Corporation, NEPA 531-NMR-29, AECU-104 (April 20, 1948).

(5) Baroody, E. M., Duckworth, W. H., Simons, E. M., and Schofield, H. Z., "Effect of Shape and Material on the Thermal Rupture of Ceramics", AECD-3486 (May 22, 1951).

(6) Brewer, L., et al., The Chemistry and Metallurgy of Miscellaneous MaterialsThermodynamics, Edited by L. L. Quill, McGraw-Hill Book Company, Inc., New York (1950).

(7) Brewer, L., and Krikorian, O., "Reactions of Refractory Silicides With Carbon and With Nitrogen", J. Electrochem. Soc., 103 (1), 38 (1956).

(8) Brewer, L., and Krikorian, O., "Reactions of Refractory Silicides With Carbon and With Nitrogen", UCRL-2544 (1954).

(9) Browning, L. C., and Emmett, P. H., "Equilibrium Measurements in the Molybdenum-Carbon-Hydrogen System", J. Am. Chem. Soc., 74, 4773-4 (1952).

(10) Cadoff, I., and Nielsen, J. P., "Titanium-Carbon Phase Diagram", J. Metals, 5, 248 (1953).

(11) Campbell, I. E. (Editor), High-Temperature Technology, John Wiley and Sons, Inc., New York (1956).

(12) Chiotti, P., "Experimental Refractory Bodies of High-Melting Nitrides, Carbides, and Uranium Dioxide", J. Am. Ceram. Soc., 35, 123 (1952).

(13) Ellinger, F. H., "The Tantalum-Carbon System", Trans. Am. Soc. Metals, 31 , 89 (1943).

(14) Finlay, G. R., "Refractories for $4000 \mathrm{~F}$ and Higher", Chemistry in Canada, $\underline{4}$, 41 (March, 1952).

(15) Gangler, J. J., Robards, C. F., and McNutt, J. E., "Physical Properties at Elevated Temperature of Seven Hot-Pressed Ceramics", National Advisory Committee for Aeronautics, Washington, D. C., Tech. Note 1911 (July, 1949); J. Am. Ceram. Soc., 23, 367 (1950). 
(16) Geller, R. F., et al., "Studies of Birary and Ternary Combinations of Magnesia, Calcia, Baria, Beryllia, Alumina, Thoria, and Zirconia in Relation to Their Use as Porcelains", J. of Research, Natl. Bur. Standards, Research Paper RP 1703, 36, 277 (1946).

(17) Glaser, F. W., and Ivanick, W., "Sintered Titanium Carbide", J. Metals, 4, 387 (1952).

(18) Green, A. T., and Stewart, G. H. (Editors), Ceramics, The British Ceramic Society, Stoke-on-Trent (1953).

(19) Harman, C. G., and O'Bannon, L. S., "Investigations Related to the Application of Nuclear Energy for the Propulsion of Aircraft", BMI-712 (April 30, 1951) CONFIDENTIAL.

(20) Hoyt, S. L., "Hard Metal Carbides and Cemented Tungsten Carbide", Trans. A. I. M.E., Inst. of Metals Div., pp 9-58 (1930).

(21) Hyde, C., Quirk, J. F., and Duckworth, W. H., "Preparation of Dense Beryllium Oxide", Preprint 126 of Am. Inst. Chem. Eng., presented at the Nuclear Engineering and Science Congress, Cleveland, Ohio, December 15, 1955.

(22) Humphrey, G. L., "The Heats of Combustion and Formation of Titanium Nitride (TiN) and Titanium Carbide (TiC)", J. Am. Chem. Soc., 73, 2261 (1951).

(23) Humphrey, G. L., "Heats of Formation of Tantalum, Niobium, and Zirconium Oxides, and Tantalum Carbide", J. Am. Chem. Soc., 76, 978 (1954).

(24) Kelley, K. K., "High-Temperature Heat-Content, Heat-Capacity, and Entropy Data for Inorganic Compounds", U. S. Government Printing Office, Washington, D. C., Bureau of Mines Bulletin 476 (1949).

(25) Kelley, K. K., "Contributions to the Data on Theoretical Metallurgy. XI. Entropies of Inorganic Substances. Revision (1948) of Data and Methods of Calculation", U. S. Government Printing Office, Washington, D. C. , Bureau of Mines Bulletin 477 (1950).

(26) Kelley, K. K., "The Specific Heats at Low Temperatures of Tantalum Oxide and Tantalum Carbide", J. Am. Chem. Soc., 62, 818 (1940).

(27) Krikorian, O. H., "High-Temperature Studies", (Thesis) University of California, Radiation Laboratory, Berkeley, California, UCRL-2888 (Apri1, 1955).

(28) Kubaschewski, O., and Evans, E. L., Metallurgical Thermochemistry, Academic Press, New York (1951).

(29) Kuo, K., and Hagg, G., "A New Molybdenum Carbide", Nature, 170, 245 (1952).

(30) Lang, Fillmore, and Roth, "The System $\mathrm{UO}_{2}-\mathrm{BeO} "$, Natl. Bur. Standards Interim Report to AEC (1952).

(31) Levin, E. M., McMurdie, H. F., and Hall, F. P., Phase Diagrams for Chemists, American Ceramic Society (1956). 


$$
35 \quad 35 \text { and } 36
$$

(32) Livey, D. T., and Murray, P., "The Stability of Beryllia and Magnesia in Different Atmospheres at High Temperatures", J. Nuclear Energy, 2, 202-212 (1956).

(33) Long, R. E., and Schofield, H. Z. , "Beryllia", AEC-TIS Reactor Handbook, $\underline{3}$, Section 1, Chapter 1.3 (1955).

(34) Mah, A. D., and Boule, B. J., "Heats of Formation of Niobium Carbide and Zirconium Carbide From Combustion Calorimetry", J. Am. Chem. Soc., 77, 6512-6513 (December 20, 1955).

(35) Mallett, M. W., and Sheipline, V. M., "Carbides", AEC-TIS Reactor Handbook, 3, Section 1, Chapter 1.7 (1955).

(36) McKenna, P. M., "Tantalum Carbide: Its Relation to Other Hard Refractory Compounds", Ind. Eng. Chem., 28, 767 (1936).

(37) Norton, F. H., Refractories, Third Edition, The McGraw-Hill Book Company, Inc., New York (1949).

(38) Pollard, F. H., and Woodward, P., "The Stability and Chemical Reactivity of Titanium Nitride and Titanium Carbide", Trans. Faraday Soc., 46, 190 (1950).

(39) Powell, C. F., Campbell, I. E., and Gonser, B. W., Vapor Plating, John Wiley and Sons, Inc., New York (1955).

(40) Quirk, J. F., "Beryllium Carbide", AEC-TIS Reactor Handbook, $\underline{3}$, Section 1, Chapter 1.5 (1955).

(41) Rossini, F. D., et al., "Selected Values of Chemical Thermodynamic Properties", U. S. Government Printing Office, Washington, D. C., Circular 500 (1952).

(42) Schwartz, M. A., "Report on Columbium Carbide", NEPA-326 (1947).

(43) Schwarzkopf, P., and Kieffer, R., Refractory Hard Metals, The Macmillan Company, New York (1953).

(44) Smithells, C. J., Metals Reference Book, Second Edition, Interscience Publishers, Inc., New York (1955).

(45) Sykes, W. P., Van Horn, K. R., and Tucker, C. M., "A Study of the Molybdenum-Carbon System", Trans. Am. Inst. Mining and Met. Eng., 117, 173 (1935).

(46) White, D. W., Jr., and Burke, J, E. (Editors), The Metal Beryllium, Am. Soc. Metals (1955).

(47) Wood, E., "Literature Survey of High Melting Point Refractories", The English Electric Company, LTD, Guided Weapons Division (April 19, 1953). 


\section{6}

\section{APPENDIX}

SUMMARY OF PROPER TIES OF HIGHTEMPERA TURE MATERIALS 


\section{3)}

TABLE A-1. SUMMARY OF PROPERTIES OF HIGH-TEMPERATURE MATERIALS(0)

\begin{tabular}{|c|c|c|c|c|c|c|c|c|}
\hline & \multirow{2}{*}{$\begin{array}{l}\text { Niobium Carbide, } \\
\text { NoC }\end{array}$} & \multicolumn{2}{|c|}{ Molybdenum Cartide } & \multicolumn{2}{|c|}{ Tantalum Carbide } & \multirow{2}{*}{$\begin{array}{l}\text { Titanium Carbide, } \\
\text { TIC }\end{array}$} & \multirow{2}{*}{$\begin{array}{l}\text { Beryllium 0xide, } \\
\text { BeO }\end{array}$} & \multirow{2}{*}{$\begin{array}{c}\text { Beryillum Carbide, } \\
\mathrm{Be}_{2} \mathrm{C}\end{array}$} \\
\hline & & MoC & $\mathrm{Mo}_{2} \mathrm{C}$ & $\mathrm{TaC}$ & $\mathrm{Ta}_{2} \mathrm{C}$ & & & \\
\hline Density, $\mathrm{g}$ per $\mathrm{cm}^{3}$ & $7.82^{(35)}$ & $8.5^{(11)}$ & $8.9^{(11)}$ & $14.49^{(36)}$ & $15.22^{(39)}$ & $4.93^{(17)}$ & $3.025^{(33)}$ & $2.44(40)$ \\
\hline Melting Point, C & $3500^{(43)}$ & $2690-2695^{(11)}$ & $2685-2690(11)$ & $3877 \pm 150^{(1)}$ & $3400^{(11)}$ & $3140^{(2)}$ & $2500 \pm 25^{(33)}$ & $\mathrm{d} 2150^{(40)}$ \\
\hline Vapor Pressure, atm & $N D^{(b)}$ & ND & ND & ND & ND & ND & $10^{-6}(3500 F)^{(46)}$ & $6 \times 10^{-3}(1627 \mathrm{C})^{(40)}$ \\
\hline Heat of Formation, $\Delta \mathrm{H}_{\mathrm{f} 298^{\circ}}^{\circ}, \mathrm{kcal}$ per $\mathrm{g}$ mole & $-33.6 \pm 0.8^{(34)}$ & $-200 \pm 0.65(7)$ & $-4.22 \pm 1.09(n)$ & $-38.5^{(23)}$ & $-36^{(8)}$ & $-43.8^{(22)}$ & ND & ND \\
\hline Free Energy of Formation, $\Delta F_{\mathrm{f} 298}^{\circ}$, kcal per $\mathrm{g}$ mole & $-33.2^{(34)}$ & $-2.0^{(11)}$ & $-4.93^{(11)}$ & $-38.1^{(23)}$ & $-36.4^{(23)}$ & $-43.0^{(22)}$ & $-140^{(46)}$ & $-7.83^{(40)}$ \\
\hline Entropy of Formation, $\Delta S_{\{298}^{\circ}, \mathrm{cal} /(\mathrm{g}$ mole)$)(K)$ & $-1.4 \pm 1^{(7)}$ & $0.0 \pm 1^{(7)}$ & $2.41 \pm 1^{(n)}$ & $1.19^{(8)}$ & $1.4^{(8)}$ & $-2.8^{(11)}$ & ND & ND \\
\hline $\begin{array}{l}\text { Heat of Fusion, kcal per g mole } \\
\text { Entropy of Fusion, cal/(g mole)(K) }\end{array}$ & ND & ND & ND & ND & ND & ND & $\begin{array}{l}\Delta H=17(2550 \mathrm{C})^{(33)} \\
\Delta \mathrm{S}=6.0(2550 \mathrm{C})^{(33)}\end{array}$ & ND \\
\hline $\begin{array}{l}\text { Heat of Vaporization, } \mathrm{kcal} \text { per g mole } \\
\text { Entropy of Vaporization, cal/(g moleXK) }\end{array}$ & ND & ND & ND & ND & ND & ND & $\begin{array}{l}\Delta H=117.0(4260 \mathrm{C})^{(33)} \\
\Delta S=25.8(4260 \mathrm{C})^{(33)}\end{array}$ & ND \\
\hline Heat of Sublımation, kcal per g mole & ND & ND & ND & ND & ND & ND & $152^{(33)}$ & ND \\
\hline Coefficient of Thermal Expansion, per deg $C$ & ND & ND & ND & $8.2 \times 10^{-6(43)}$ & ND & $7.4 \times 10^{-6(11)}$ & $10.8 \times 10^{-6(33)}$ & $10.5 \times 10^{-6(40)}$ \\
\hline Thermal Conductivity, $\mathrm{cal} /(\mathrm{sec})\left(\mathrm{cm}^{2}\right)(\mathrm{C} / \mathrm{cm})$ & $0.034^{(11)}$ & ND & ND & $0.053^{(11)}$ & ND & $0.041^{(43)}$ & $0.4^{(46)}$ & $0.05(11)$ \\
\hline Heat Capacity, $C_{p 298}, \mathrm{cal} /(\mathrm{g}$ mole $)(\mathrm{C})$ & ND & ND & ND & $8.79^{(25)}$ & ND & $8.04^{(25)}$ & $9^{(46)}$ & $0.334 \pm 0.013^{(40)}$ \\
\hline Debye Temperature, C & ND & ND & NO & ND & ND & No & $1280^{(46)}$ & ND \\
\hline Electrical Resistivity, ohm-cm & $\begin{array}{l}(25 \mathrm{C}) 7.4 \times 10^{-5(43)} \\
(3500 \mathrm{C}) 3-4 \times 10^{-4(42)}\end{array}$ & $(20 \mathrm{C}) 4.9 \times 10^{-5(43)}$ & $(20 \mathrm{C}) 9.75 \times 10^{-5(43)}$ & 17 to $3.0 \times 10^{-5(11)}$ & ND & $6.8 \times 10^{-5(17)}$ & ND & $(30 \mathrm{C}) 0.063^{(40)}$ \\
\hline Dielectric Coefficient & ND & ND & ND & ND & ND & ND & $7.3^{(46)}$ & ND \\
\hline Magnetic Susceptiblity, cgs emu & ND & ND & ND & $0.45 \times 10^{-6(43)}$ & ND & $0.12 \times 10^{-6(43)}$ & $-(0.477 \pm 0.008) \times 10^{-6(46)}$ & ND \\
\hline Modulus of Elasticity, pst & $49.4 \times 10^{6(43)}$ & ND & $327 \times 10^{6(43)}$ & $41.5 \times 10^{6(43)}$ & ND & $45 \times 10^{6(43)}$ & $55 \times 10^{6(11)}$ & $45.6 \times 10^{6(46)}$ \\
\hline Poisson's Ratio, pSI & ND & ND & ND & ND & ND & No & 0.23 & $0.10^{(46)}$ \\
\hline Tensile Strength, DSI & ND & ND & ND & ND & ND & ND & $18,500^{(46)}$ & ND \\
\hline Compressive Strength, psI & ND & ND & ND & ND & ND & ND & $200,000^{(46)}$ & $105,000^{(46)}$ \\
\hline Mohs Harchess & 9 to $10^{(42)}$ & 7 to $9^{(43)}$ & 7 to $\mathrm{g}^{(43)}$ & $9_{+}^{(43)}$ & ND & 9 to $10^{(43)}$ & $g^{(33)}$ & $9_{+}^{(11)}$ \\
\hline Microhardness, kg per mm² & $2400^{(43)}$ & ND & $1800^{(43)}$ & $1800-2000(13)$ & ca $10000^{(13)}$ & $3200^{(43)}$ & ND & ND \\
\hline Crystal Structure & $\begin{array}{l}\text { Face-centered cubic } \\
\qquad(\text { NaCl type })^{(42)}\end{array}$ & Hexagonal $(43)$ & Hexagonal ${ }^{(43)}$ & Face-centered cubic ${ }^{(43)}$ & Hexagonal|(43) & Face-centered cubic ${ }^{(43)}$ & Hexagonal(33) & Cubic ant fluorite ${ }^{(40)}$ \\
\hline Lattice Constants, A & 4.4584 to $4.462^{(43)}$ & $a_{0}=2901, c_{0}=2768(11)$ & $a_{0}=2994, c_{0}=4.72^{(11)}$ & $a_{c}=4.445^{(36)}$ & $a_{0}=3.091, c_{0}=4.93^{(43)}$ & $a_{0}=4.32^{(43)}$ & $a_{0}=2.69, c_{0}=4.39^{(33)}$ & $a_{0}=4.344^{(40)}$ \\
\hline
\end{tabular}

(a) Superscript numbers refer to references in Biblography at end of the text.

(b) $\mathrm{ND}=$ no data avallable. 